\title{
Critical Review on Zeolite Clinoptilolite Safety and Medical Applications in vivo
}

\author{
Sandra Kraljević Pavelić1*, Jasmina Simović Medica², Darko Gumbarević1, \\ Ana Filošević ${ }^{1,}$ Nataša Pržulj ${ }^{3}$ and Krešimir Pavelić ${ }^{1,4}$ \\ 1 Department of Biotechnology, Centre for High-Throughput Technologies, University of Rijeka, Rijeka, Croatia, \\ 2 General Hospital Pula, Pula, Croatia, ${ }^{3}$ Computer Science Department, University College London, London, \\ United Kingdom, ${ }^{4}$ Juraj Dobrila University of Pula, Pula, Croatia
}

OPEN ACCESS

Edited by:

LeiXi,

Virginia Commonwealth University,

United States

Reviewed by:

Panagiotis Dimitrios Katsoulos, Aristotle University of Thessaloniki,

Greece

Stephane Nizet,

GLOCK Health, Science and Research G.m.b.H., Austria

${ }^{*}$ Correspondence: Sandra Kraljević Pavelic sandrakp@biotech.uniri.hr

Specialty section:

This article was submitted to Translational Pharmacology, a section of the journal

Frontiers in Pharmacology

Received: 20 June 2018 Accepted: 02 November 2018 Published: 27 November 2018

Citation:

Kraljević Pavelić S, Simović Medica J, Gumbarević D, Filošević A, Pržulj N and Pavelić K (2018) Critical Review on Zeolite Clinoptilolite Safety

and Medical Applications in vivo.

Front. Pharmacol. 9:1350.

doi: 10.3389/fphar.2018.01350
Unique and outstanding physical and chemical properties of zeolite materials make them extremely useful in a variety of applications including agronomy, ecology, manufacturing, and industrial processes. Recently, a more specific application of one naturally occurring zeolite material, clinoptilolite, has been widely studied in veterinary and human medicine. Due to a number of positive effects on health, including detoxification properties, the usage of clinoptilolite-based products in vivo has increased enormously. However, concerns have been raised in the public about the safety of clinoptilolite materials for in vivo applications. Here, we review the scientific literature on the health effects and safety in medical applications of different clinoptilolite-based materials and propose some comprehensive, scientifically-based hypotheses on possible biological mechanisms underlying the observed effects on the health and body homeostasis. We focus on the safety of the clinoptilolite material and the positive medical effects related to detoxification, immune response, and the general health status.

Keywords: zeolite, clinoptilolite, toxicology, immunostimulation, antioxidant properties

\section{CHEMICAL PROPERTIES AND BIOLOGICAL APPLICATION OF NATURAL ZEOLITE CLINOPTILOLITE}

Zeolites possess unique and outstanding physical and chemical properties. These characteristics make them very useful in a variety of applications including agronomy, ecology, certain manufacturing, industrial processes, medicine, and cosmetics. Recently, the application of a specific natural zeolite material, clinoptilolite, has been documented in veterinary and human medicine.

Abbreviations: 5-HT(1A) and 5-HT(1B), serotonergic 5-hydroxytryptamine receptors in the brain; 3H-8-OH-DPAT, $3[\mathrm{H}] 8$-hydroxy-2-(di-n-propylamino)tetralin; $\mathrm{Al}$, aluminum; $\mathrm{Al}^{3+}$, aluminum(III)-cation; $\mathrm{ALT}$, aspartate aminotransferase; AST, alanine aminotransferase; $\mathrm{Ba}$, barium; $\mathrm{Ca}$, calcium; $\mathrm{Co}$, cobalt; $\mathrm{CO}_{2}$, carbon dioxide; $\mathrm{Cd}$, cadmium; $\mathrm{Cr}$, chromium; Cs, caesium; Cu, copper; EDTA, ethylenediaminetetraacetic acid; EFSA, The European Food Safety Authority; EGF-R, epidermal growth factor receptor; Fe, iron; GALT, gut-associated lymphoid tissue; GGT, gamma-glutamyl transferase; GSH, glutathione; HEU, clinoptilolite; $\mathrm{Hg}$, mercury; $\mathrm{H}_{2} \mathrm{~S}$, hydrogen sulfide; $\mathrm{H}_{2} \mathrm{O}_{2}$, hydrogen peroxide; $\mathrm{K}$, potassium; $\mathrm{Mn}$, manganese; MALT, mucosa-associated lymphoid tissue; MDA, malondialdehyde; $\mathrm{Na}$, sodium; NfkB, nuclear factor kB; $\mathrm{Ni}$, nickel; $\mathrm{O}_{2}^{--}$, superoxide anion; OECD, Organization for Economic Cooperation and Development; $\cdot \mathrm{OH}$, hydroxyl radical; $\mathrm{Pb}$, lead; (PKB)/Akt, protein kinase B/Akt kinase; PMA, micronized clinoptilolite material; Prx, peroxiredoxin; ROS, reactive oxygen species; Si, silicon; SOD, superoxide dismutase; Sr, strontium; TCLP/EPA/RCRA, Toxicity Characteristic Leaching Procedure/Environmental protection agency/Resource Conservation and Recovery Act; Trx, thioredoxin; Zn, zinc. 


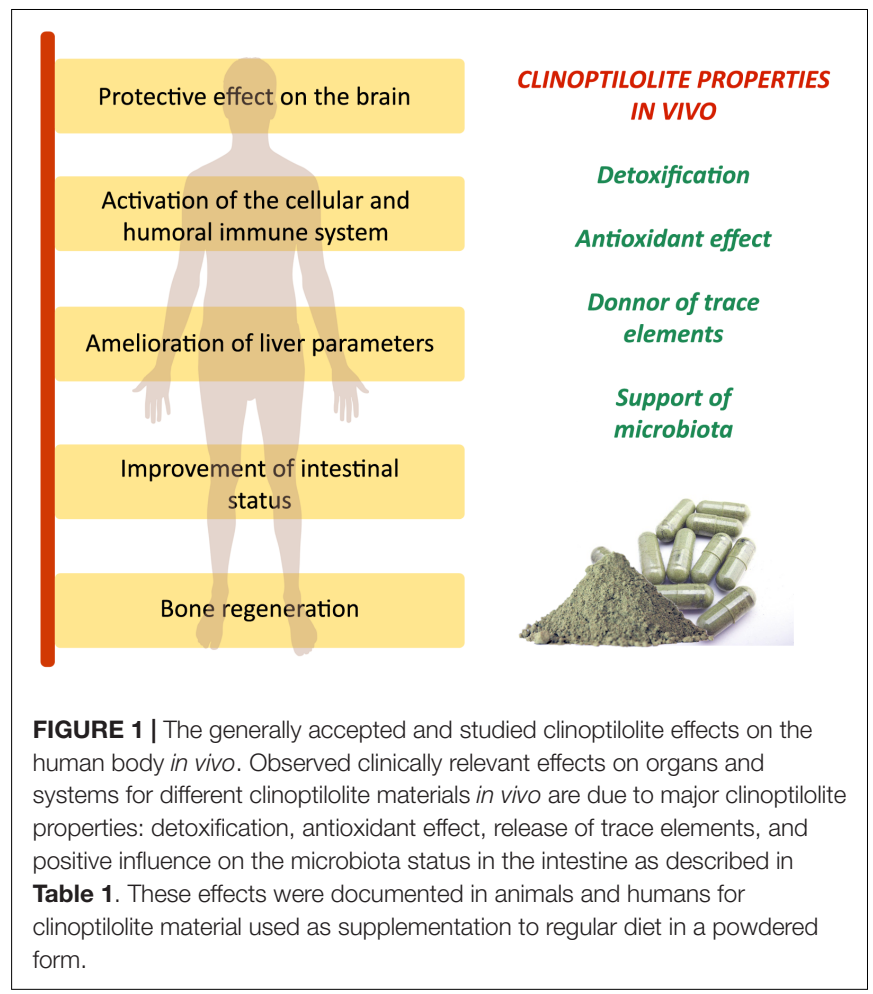

Subsequently, the market of clinoptilolite-based products for use in vivo has been continuously growing (Figure 1) (Pavelić and Hadžija, 2003).

The name 'zeolite' originates from the Greek words 'zeo'(to boil) and 'litos' (a stone). The current nomenclature and classification of zeolite materials has been provided by the Structure Commission of the International Zeolite Association that identifies each material based on their framework with a three-letter mnemonic code; for instance, natural zeolite clinoptilolite is denoted as HEU (Baerlocher et al., 2007).

By origin, zeolites can be natural or synthetic materials. They are aluminosilicate minerals with rigid anionic frameworks containing well-defined channels and cavities. These cavities contain metal cations, which are exchangeable, or they may also host neutral guest molecules that can also be removed and replaced. The majority of natural zeolites are of volcanic origin and have a general formula, $\mathrm{M} 2 / \mathrm{n}: \mathrm{Al}_{2} \mathrm{O}_{3}: \mathrm{xSiO}_{2}: \mathrm{yH}_{2} \mathrm{O}$, where $\mathrm{M}$ stands for the extra-framework cation (Bogdanov et al., 2009). The mineral structure is based on $\mathrm{AlO}_{4}$ and $\mathrm{SiO}_{4}$ tetrahedra, which can share 1,2 , or 3 oxygen atoms, so there is a wide variety of possible structures as the network is extended in three dimensions. This unique structural feature is a basis for their well-known microporous structure. Based on the pore size and absorption properties, zeolites are among the most important inorganic cation exchangers and are used in industrial applications for water and waste water treatment, catalysis, nuclear waste, agriculture, animal feed additives, and in biochemical applications (Bogdanov et al., 2009).

The variety of zeolites' application is indeed a consequence of their porous structure: pores form negatively charged channels and cavities, which are occupied with positively charged alkali, and alkali earth monovalent (i.e., $\mathrm{Na}^{+}, \mathrm{K}^{+}$), and divalent (i.e., $\mathrm{Ca}^{2+}$ ) ions, $\mathrm{OH}$-groups or $\mathrm{H}_{2} \mathrm{O}$ molecules, which can be easily exchanged by other molecules and cations from the surroundings (Figure 2). It is logical then, that the final $\mathrm{Si} / \mathrm{Al}$ ratio in a zeolite determines the ion exchange capacity and attraction of cations that come to reside inside the pores and channels (Mumpton, 1999; Canli et al., 2013a).

Besides metal cations and water resident in zeolites' cavities and pores, other molecules and cationic groups may be accommodated as well, such as, for instance, ammonia, and nitrate ions, all of which are bound to different zeolites at different affinity levels (Gaikwad and Warade, 2014). For example, selectivity alignments of the zeolite clinoptilolite cation exchange have been given as $\mathrm{Ba}^{2+}>\mathrm{Cu}^{2+}$, $\mathrm{Zn}^{2+}>\mathrm{Cd}^{2+}, \mathrm{Sr}^{2+}>\mathrm{Co}^{2+}$ by Blanchard et al. (1984), as $\mathrm{Pb}^{2+}>\mathrm{Cd}^{2+}>\mathrm{Cs}^{+}>\mathrm{Cu}^{2+}>\mathrm{Co}^{2+}>\mathrm{Cr}^{3+}>\mathrm{Zn}^{2+}>\mathrm{Ni}^{2+}>$ $\mathrm{Hg}^{2+}$ by Zamzow et al. (1990), or as $\mathrm{Co}^{2+}>\mathrm{Cu}^{2+}>\mathrm{Zn}^{2+}>$ $\mathrm{Mn}^{2+}$ by Erdem et al. (2004).

The mineral assemblies of the most common zeolite occurrences in nature are clinoptilolite- and mordenitecontaining tuffs, in which the zeolite clinoptilolite and mordenite content is high ( $80 \%$ and over). It may appear with the aluminum phyllosilicate clay smectite (bentonite) and accompanying phases present in lower percentages cristoballite, calcite, feldspar, and quartz. However, other types of zeolites (e.g., phillipsite, chabazite) and clay minerals may dominate the mineral tuff assemblage, and properties of such materials may vary in the widest sense with respect to the final mineral content (Cejka, 2005).

The widely tested zeolite suitable for medical applications in vivo is the clinoptilolite tuff but the mordenite tuff was also studied by Selvam et al. (2014) So far the word 'zeolite' has been used in the literature for different types of zeolites, tuffs, and clays. For example, both clinoptilolite and clay materials may be used for ion-exchange reactions. Still, their structural properties and toxicology profiles may be different (Maisanaba et al., 2015). The structure of mineral clays is, for instance, organized in layers (sheets), while clinoptilolite has tetrahedra arranged in a way that they form large amounts of pore space in the crystals. Different physical-chemical properties between clinoptilolite and clays, e.g., kaolinite were documented accordingly in the literature (Ghiara et al., 1999; Miranda-Trevino and Coles, 2003; Payra and Dutta, 2003; Hecht, 2005; Svoboda and Šulcová, 2008; Bibi, 2012; Dimowa et al., 2013; Jurkić et al., 2013). For example, the kaolinite structure may change during the ion-exchange processes due to the displacement of $\mathrm{H}^{+}$ions or due to the swelling of the structure as a consequence of $\mathrm{Pb}, \mathrm{Zn}$, or $\mathrm{Cd}$ cations absorption, which is opposite to the clinoptilolite constancy during ionexchange process (Miranda-Trevino and Coles, 2003).

Clinoptilolite shares a high structural similarity with the zeolite heulandite (they are isostructural) and it is distinguished from helaundite by a higher silicon to aluminum ratio in favor to silicon, where $\mathrm{Si} / \mathrm{Al}>4.0$ and $(\mathrm{Na}+\mathrm{K})>(\mathrm{Ca}+\mathrm{Sr}+\mathrm{Ba})$. The thermal behavior of clinoptilolite and heulandite is also different. The clinoptilolite structure is still not destroyed after $12 \mathrm{~h}$ of heating at $750^{\circ} \mathrm{C}$, whereas the heulandite structure is destroyed 


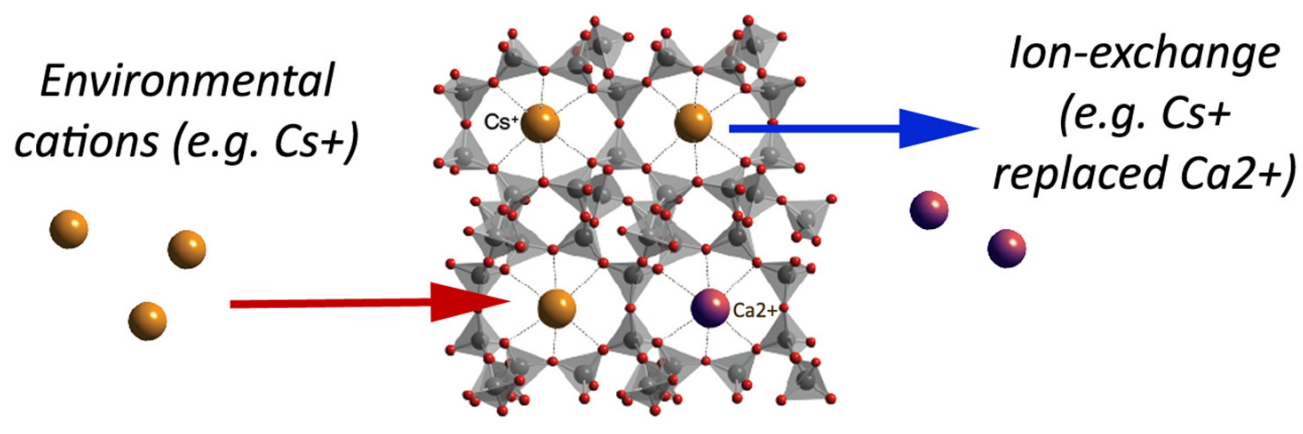

FIGURE 2 | A simplified schematic of the clinoptilolite structure: linked $\mathrm{SiO}_{4}$ tetrahedra and pores with metal cations available for ion-exchange with environmental cations (e.g., caesium, $\mathrm{Cs}^{+}$) that are consequently trapped into the clinoptilolite pores. As naturally occurring clinoptilolite comes with pre-loaded cations (e.g., calcium, $\mathrm{Ca}^{2+}$ ), ion-exchange may occur depending on the ion-exchange capacity and cation affinity of the material, as well as on physical properties of the surrounding environment. In the herein presented simplified example, $\mathrm{Cs}^{+}$enters in the zeolite pores instead of $\mathrm{Ca}^{2+}$ (adapted from http://www.chemtube3d.com/solidstate/SS-Z-Clinoptilolite.htm Creative Commons Attribution-Non-commercial-Share Alike 2.0 UK: England and Wales License). A detailed explanation of the clinoptilolite structure is given in the Database of Zeolite Structures (http://europe.iza-structure.org/IZA-SC/ftc_table.php).

after $12 \mathrm{~h}$ at $450^{\circ} \mathrm{C}$ (Ghiara et al., 1999). This structural stability is an essential element for in vivo applications.

For instance, a synthetic material known as Zeolite A, used widely for ion-exchange in industrial processes, has the framework composition with a high $\mathrm{Al}$ content and the molar ratio of $\mathrm{Si} / \mathrm{Al}$ of almost 1 . This is indeed the highest aluminum content possible in tetrahedral alumosilicate frameworks (Payra and Dutta, 2003). In Zeolite A, the Al-framework is balanced out by the maximum number of cation exchange sites; it has high cation contents and superior exchange capacities. However, it is not appropriate for in vivo applications since, similar to other low-silica zeolites, zeolite A is unstable in acids. In contrast, zeolites with higher silica content, such as clinoptilolite, are stable in acids (Payra and Dutta, 2003).

We present a comprehensive review of clinoptilolite applications in veterinary and human medicine. We consider all of the above clinoptilolite properties and propose its mechanisms of action in vivo (summarized in Table 1) and propose some comprehensive, scientifically-based hypotheses on possible biological mechanisms underlying observed effects on the health and body homeostasis.

\section{USE OF CLINOPTILOLITE IN VETERINARY AND HUMAN MEDICINE}

Studies performed in the last decades showed a high potency of clinoptilolite in diverse medical applications in vitro and in vivo (Jurkić et al., 2013). A large number of documented positive clinoptilolite medical effects were attributed to basic clinoptilolite material properties, in particular, to reversible ion-exchange and adsorption capacity (Mumpton, 1999; Pavelić et al., 2001a; Jurkić et al., 2013). This central clinoptilolite characteristic related to elimination of toxic agents, which may be seen as a support to the 'body homeostasis,' could be widely exploited in a number of medical applications. For instance, a high affinity of clinoptilolite toward ammonia was proven in different systems for elimination of ammonia from water (Demir et al., 2002; Sprynskyy et al., 2005; Zabochnichka-Światek and Malinska, 2010). This is why clinoptilolite has widely been used for years in animal production as an additive to animal feed, or for the removal of ammonia in animal manure (Auerbach et al., 2003). This ammonia affinity is an interesting feature for medical applications in humans as well. For example, detrimental roles of the end-products of protein

TABLE 1 | Documented properties and effects of clinoptilolite relevant for biomedical applications and effects in animals and humans.

Clinoptilolite properties

Cation exchange capacity (Mumpton, 1999; Pavelić et al., 2001a; Pavelić and Hadžija, 2003)

Molecular sieve (size and shape selectivity) (Mumpton, 1999; Pavelić and Hadžija, 2003)

Selective adsorption of water (Kotova et al., 2016)

Removal of ammonia ions and uremic toxins (urea, uric acid, creatinine, p-cresol, indoxyl sulfate) (Demir et al., 2002; Auerbach et al., 2003; Sprynskyy

et al., 2005; Joughehdoust and Manafi, 2008; Zabochnichka-Światek and

Malinska, 2010)

Reversible binding of small molecules (Pavelić and Hadžija, 2003)

Biosensors (Soldatkin et al., 2015)

Drug carrier/delivery (Hayakawa et al., 2000; Bonferoni et al., 2007)

\section{Clinoptilolite effects}

Detoxicant, mineral donor (EFSA Panel on Additives and Products or Substances used in Animal Feed, 2013; Jurkić et al., 2013; Exley, 2016; Kraljević Pavelić et al., 2017)

Impact on the intestine status (Yao et al., 2016)

Immunomodulation (Ivkovic et al., 2004; Montinaro et al., 2013)

Effect on pathogens and microbiota (Zarkovic et al., 2003; Saribeyoglu, 2011; Prasai et al., 2016)

Enzyme mimetics, metaloenzyme mimicry (Herron, 1989)

Antitumor adjuvant (Wesley, 1996; Krewski et al., 2009)

Vaccine adjuvant (Garces, 1999) 
fermentation, such as ammonia, have been recognized on the colonic microbiota and epithelial health, in particular on the colonocytes life span and function (Hughes and Magee, 2000; Yao et al., 2016; Hamid Said, 2018).

The excessive production of ammonia, but also of other gaseous products, including $\mathrm{CO}_{2}$ and $\mathrm{H}_{2} \mathrm{~S}$, may occur as a consequence of protein-rich or imbalanced diets, or in diverse pathogeneses where excessive protein fermentation occurs, including irritable bowel syndrome, ulcerative colitis, and colorectal carcinogenesis (Hughes and Magee, 2000; Yao et al., 2016). Clinoptilolite has a high affinity toward ammonium and may prove useful in these cases as an adjuvant to the standard therapy (Yao et al., 2016). From this perspective, clinoptilolite was evaluated in a recent trial performed on aerobically trained subjects (Lamprecht et al., 2015). In this study, endurancetrained subjects were recruited and supplemented with a clinoptilolite/dolomite/maca-based product (Panaceo Sport ${ }^{\circledR}$ ). Athletes, indeed, often report intestinal symptoms including nausea, stomach and intestinal cramps, vomiting, and diarrhea. These symptoms may be a consequence of typical athletes' diets with high protein content, as in such circumstances excessive protein fermentation may occur and is accompanied by higher ammonia release in the intestine as well. These subjects also have increased intestinal wall permeability. A well-known and complex relationship between exercise and oxidative stress depends on many diverse factors. For instance, regular moderate exercise increases the resistance against oxidative stress, while acute and vigorous exercise can generate free radicals in excess. Consequences of exercise at exhaustion levels include increased number of leukocytes due to the damage of muscle fibers and connective tissue (Morillas-Ruiz and Hernández-Sánchez, 2015) as well as elevated lipid-peroxidation marker MDA in the plasma (Pingitore et al., 2015). It is, therefore, not surprising that a number of professional athletes show gastrointestinal symptoms, which may result in medical problems, infections, and autoimmune disease (Waterman and Kapur, 2012; Oliveira et al., 2014). Interestingly, the supplementation with Panaceo Sport positively influenced the intestinal wall integrity, which was witnessed through decreased concentrations of the tight junction modulator zonulin, a marker of increased intestinal permeability (Lamprecht et al., 2015).

Other studies on detoxification properties of clinoptilolite materials in vivo performed so far have mainly been done on animals and they provide strong evidence on alleviating effects during exposure to different toxicants upon clinoptilolite supplementation. For instance, a prolonged consumption of water with increased nitrate levels by dairy cattle is known to impair protein metabolism and glucose utilization. In these cows, dietary administration of clinoptilolite alleviated the nitrate burden to the body and reduced the negative systemic effects of nitrates (Katsoulos et al., 2015). Similarly, a dietary mixture containing $3 \%$ of a clinoptilolite-based product showed an increase in the nitrogen excretion in feces and a decrease in the nitrogen excretion in urine in growing pigs. Importantly, no effects on the protein retention values were observed and the protein deposition was not altered (Poulsen and Oksbjerg, 1995; Laurino and Palmieri, 2015).
Moreover, clinoptilolite incorporated into the diet may be effective in fighting mycotoxins by direct absorption. Affinity toward aflatoxins, zearalenone, ochratoxin, and the T2 toxin was proven in vitro in the presence of aminoacids and vitamins, where the latter were not absorbed by the clinoptilolite material (Tomasevic-Canovic et al., 1996). The specificity for aflatoxin M1 was also shown in vivo, and the dietary administration of clinoptilolite, especially of the material with the smallest particle size at the rate of $200 \mathrm{~g}$ per cow per a day, effectively reduced milk aflatoxin M1 concentration in dairy cattle (Katsoulos et al., 2016).

It is important to note that the supplementation with clinoptilolite in dairy cows may have additional benefits, such as the reduction of parturient paresis. A study by Katsoulos et al. (2005a), for instance, showed that the clinoptilolite supplementation reduced its incidence and did not affect serum concentrations of total calcium, phosphate, magnesium, potassium, and sodium. This veterinary application showed that mineral levels in the blood were not affected by clinoptilolite supplementation which may be relevant for human applications as well. Indeed, the demand for healthier food products and a balanced diet is being increasingly recognized as a central paradigm for the preservation of the body's homeostasis and health. Moreover, it is widely known that the contamination of poultry by food-borne pathogens is considered a major problem in the poultry industry. This is why antibiotics are standardly used in poultry meat production. Such a wide use of antibiotics in poultry, but also in the production of other meat, has recently been accepted as a major cause for development of antibiotic-resistant bacteria (Aminov and Mackie, 2007). New, natural possibilities for improvement of animal health in meat production have therefore been widely discussed (Diaz-Sanchez et al., 2015) and clinoptilolite may be a natural alternative.

For instance, clinoptilolite has been tested as a possible supplementation to broilers feed as an alternative to antibiotics for: (1) the control of the total flora at broiler farms, where clinoptilolite supplementation showed a positive effect on the total flora, a parameter often used in the evaluation of the gastrointestinal health status in poultry (Mallek et al., 2012), as well as on the performance of production and organoleptic parameters, especially on the increase of omega-3 fatty acid levels in eggs (Mallek et al., 2012); (2) the improvement of the antioxidant capacity in broilers where the supplementation of clinoptilolite materials increased the activities of glutathione peroxidase, catalase, total SOD, and the total antioxidant capacity (Wu Y. et al., 2013); (3) the reduction of mycotoxin effects on broilers health, where the number of aflatoxin-affected broilers, or the number of severe lesions in the liver of chickens, was reduced in the clinoptilolite-supplemented group (Ortatatli and Oğuz, 2001). All these documented effects are due to the clinoptilolite capacity to adsorb harmful substances in the gastrointestinal tract that are not confined only to micotoxins and ammonia but include heavy metals and organic compounds as well.

Indeed, different studies have shown that clinoptilolite materials provide direct detoxifying performance in vivo. For instance, in lead-intoxicated mice, a clinoptilolite sorbent KLS10-MA decreased the lead accumulation in the intestine by 
more than 70\% (Beltcheva et al., 2012, 2015). Moreover, in rats exposed to organophosphate poisoning, zeolite tuff containing $61 \%$ of clinoptilolite and added $5 \mathrm{~min}$ prior to intoxication at dosage $1 \mathrm{~g} / \mathrm{kg}$, proved efficient in the restoration of cholinesterase activity in the brain, liver, spleen, femoral muscle, heart, stomach, duodenum, colon, and erythrocytes of intoxicated animals (Mojzis et al., 1994). Two possible ways of binding organophosphates may be envisaged. One is the esterification reaction of the free $\mathrm{OH}$ moiety and the carboxyl functional group of the acid. The second option is through adsorption by forming a dipol-dipol interaction between the polar channel and/or the zeolite surface and fluorine, or on the acid. It can generally be stated that clinoptilolite loaded with potential toxicants in the intestine is then excreted along with toxicants (EFSA Panel on Additives and Products or Substances used in Animal Feed, 2013).

It seems that this detoxifying effect may have additional systemic effects. The role of clinoptilolite has been recognized in medical applications, where its usage in zootechnology and veterinary medicine has provided strong evidence on improvement of pets' fitness and efficiency in the removal of numerous harmful substances from the organism, including radioactive elements, mycotoxins, and poisons (Laurino and Palmieri, 2015). In addition, EDTA and clinoptilolite supplementation exerted a protective effect on the brain tissue of mice intoxicated with lead by inducing antioxidant mechanisms and greater activity levels of catalase, SOD, glutathione peroxidase, and glutathione (Basha et al., 2013). Moreover, a study in humans showed the ability of tribomechanically micronized clinoptilolite to decrease the absorption of ingested ethanol by reducing blood alcohol levels at a dose of $5 \mathrm{~g}$ (Federico et al., 2015). If the clinoptilolite-containing product dosage is lower or if it is not administered at the time of alcohol consumption, this effect may not be visible as shown by Gandy et al. (2015) where clinoptilolite still proved highly efficient in the reduction of veisalgia symptoms and signs up to $40-50 \%$.

In addition, clinoptilolite has interesting antioxidant, hemostatic, and anti-diarrheic properties that may be exploited in human medicine, especially as adjuvants to standard therapies (Pavelić and Hadžija, 2003). However, the number of clinical studies with clinoptilolite materials on humans is still low, and the previously described immunomodulatory, anticancer, and antioxidant effects of clinoptilolite in vivo should be studied in more detail.

Even though the efficacy and potential of clinoptilolite materials in medicine seems high, questions have been raised on to possible clinoptilolite effects on physiologically relevant elements, i.e., micronutrients and trace elements, or effects on important processes in the organism. The results published thus far show that clinoptilolite does not affect the homeostasis of trace elements and micronutrients, but acts rather selectively on heavymetals and toxicants. For instance, clinoptilolite-treated dairy goats showed no changes in serum concentrations of fat-soluble vitamins, macro-elements, and trace elements, or activities of hepatic enzymes. In addition, clinoptilolite supplementation improved milk fat percentage and milk hygiene (Katsoulos et al., 2009). No effects of clinoptilolite on physiological mineral levels have been observed in cows (Katsoulos et al., 2005a; Valpotić et al., 2017).

\section{ZEOLITES EFFECTS ON OXIDATIVE STRESS AND IMMUNE SYSTEM}

In aerobic organisms, production of small quantities of ROS, including peroxides, superoxides, hydroxyl radicals, and singlet oxygen, occurs continuously (Hayyan et al., 2016). A controlled production of ROS is indeed essential to the body's homeostasis (Covarrubias, 2008), while an excessive production of ROS is known to cause damage to the DNA, proteins, and lipids (Gulam and Ahsan, 2006). Some ROS are produced endogenously, while others are derived exogenously, such as those formed by ionizing radiation. The endogenous sources of ROS are the mitochondria, cytochrome P450 metabolism, peroxisomes, and inflammatory cell activation (Inoue et al., 2003). For example, mitochondria-produced ROS are the superoxide anion $\left(\mathrm{O}_{2}^{\bullet-}\right)$, hydrogen peroxide $\left(\mathrm{H}_{2} \mathrm{O}_{2}\right)$, and the hydroxyl radical $(\cdot \mathrm{OH})$. Other routes and factors may induce ROS in the organism as well, such as ROS produced through the activity of xanthine oxidase, in reactions of hypoxanthine to xanthine and xanthine to uric acid conversions, where molecular oxygen is reduced to superoxide anion, followed by a generation of hydrogen peroxide (Valko et al., 2004). It is understood that homeostasis in normal cells includes a balance between ROS production and antioxidant defense activity. Indeed, antioxidant mechanisms in the human body, which are the main regulators of ROS levels, are based on enzyme and non-enzyme systems. Enzyme systems rely mainly on SOD, catalase, peroxiredoxin (Prx), thioredoxins (Trx), and glutathione (GSH) enzymes' activity, while non-enzymatic systems comprise flavonoids, vitamin A, vitamin C, vitamin $\mathrm{E}$, and melatonin (Rahman, 2007). In addition to these antioxidant systems inherent to the body, other exogenous antioxidants are important in the regulation of constant body's ROS homeostasis as well. For example, dietary compounds are highly important for elimination of excessive ROS caused by external stimuli and include, for instance, carotenoids, tocopherols, bioflavonoids, anthocyanins, and phenolic acid (Smilin Bell Aseervatham et al., 2013). When ROS production exceeds antioxidant capacity, we usually perceive the process as "oxidative stress" that leads to organic damage. Increased oxidative damage to cells and tissues and the modulation of the ROS-regulated signaling pathways have recently been acknowledged in the pathogenesis of a wide number of diseases, including obesity, atherosclerosis, heart failure, uremic cardiomyopathy, kidney pathologies, hypertension, neurological disease, and cancer (Chen et al., 2016; Miranda-Díaz et al., 2016; Patel, 2016; Srikanthan et al., 2016; Ding et al., 2017). It should be noted that for a proper functioning of the body, antioxidant defenses, co-factors, or molecules that activate enzymes by binding to their catalytic sites are also required. In case of antioxidant enzymes, these co-factors may include the coenzyme Q10, vitamins B1 and B2, carnitine, selenium, and often transition metals $\mathrm{Cu}, \mathrm{Mn}, \mathrm{Fe}$, and $\mathrm{Zn}$ (Khalid, 2007). Recently, a preliminary efficacy study performed on patients with dyslipidemia has also shown a positive effect of 
clinoptilolite supplementation on lowering the total lipid count and LDL (low density lipoproteins), which may also be indirectly correlated with its general antioxidative effect (Cutovic et al., 2017).

Due to a certain amount of pre-loaded elements, it is possible to assume that clinoptilolite may positively affect the body's metal homeostasis, including either the levels or the availability of some physiological metal ions that are pre-loaded in the material, on signal pathways responsible for the production of endogenous antioxidant enzymes. Still, no direct data supports these assumptions that may partially explain the observed effects on the oxidative stress defense mechanisms, which are visible as activation or restoration of activity and levels of natural antioxidant enzymes. Still, this effect should be evaluated along with factors such as, for example, the applied daily dosage, health status, or lifestyle. For example, in the study of Lamprecht et al. (2015), the daily dosage of $1.85 \mathrm{~g}$ clinoptilolite material supplementation did not show an effect on the measured redox markers in the blood of healthy athletes. Furthermore, interesting effects of clinoptilolite supplementation were documented in animals as well. In hepatectomized rats, for instance, common oxidative stress markers are induced upon trauma, including MDA in the plasma and liver tissue. When hepatectomized rats were supplemented with a micronized clinoptilolite preparation, 'Froximun', MDA levels were significantly lower, while liver tissue antioxidant mechanisms were strengthened, as witnessed by a significantly higher activity of $\mathrm{Cu}-\mathrm{Zn}$ SOD and GSH (Saribeyoglu, 2011). Also, in chicken, daily supplementation with a natural clinoptilolite, or a modified clinoptilolite, efficiently improved the antioxidant capacity by increasing the antioxidant enzyme activities in intestine mucosa and decreasing the free radical NO content and inducible nitric oxide synthase activity in the serum. Moreover, upon prolonged supplementation in chicken, both tested clinoptilolite materials increased the activities of glutathione peroxidase, catalase, total SOD, and the total antioxidant capacity (Wu Q.J. et al., 2013). Similarly, in doxorubicin treated mice, micronized clinoptilolite proved efficient in counteracting lipid peroxidation in the liver (Zarkovic et al., 2003).

An interesting effect of clinoptilolite was observed in fluoride-intoxicated rats (Madhusudhan et al., 2009). Fluoride is neurotoxic upon penetration through the blood-brain barrier during gestation and post-gestation periods. As a consequence of fluoride-intoxication, inhibition of antioxidant enzymes occurred in pups along with lipid peroxidation. Upon supplementation of pups with clinoptilolite, oxidative damage was restored and levels of GSH-Prx were substantially ameliorated in the cerebral cortex and medulla oblongata. Similar results were, however, observed in animals supplemented with vitamins $\mathrm{E}$ and $\mathrm{C}$ as well (Madhusudhan et al., 2009). In line with these results, it should also be hypothesized that clinoptilolite might have the potential to combat acute fluorideintoxication in animals, as well as in humans. In the gastric juice, fluoride anions are converted into hydrofluoride acid. Such a weak hydrofluoride acid may form hydrogen bonds with the clinoptilolite framework and be eliminated from the body in the stool.
We believe that exact mechanisms of clinoptilolite effects on systemic restoration of homeostasis and increased antioxidant capacity are still not fully understood, as these effects are in our opinion probably connected both to general detoxifying effects occurring in the intestine, to immunomodulatory effects, or even to the release of physiologically-relevant cations from the clinoptilolite framework during the ion exchange process, e.g., $\mathrm{Ca}, \mathrm{Mn}, \mathrm{Zn}$, and $\mathrm{Mg}$, which are then readily available to the organism and the antioxidant mechanism. Similar indirect effects of clinoptilolite on the antioxidant mechanisms in the body were also observed in different pathologies and disease models. For instance, tribomechanically-micronized zeolite increased SOD activity in a transgenic mouse model of the Alzheimer disease in the hippocampus and cortex, while it concomitantly reduced $\mathrm{A} \beta(\mathrm{x}-42)$ amyloid beta levels in the hippocampus (Montinaro et al., 2013). Moreover, zinc-bearing clinoptilolite proved to exert a protective effect on the performance and gut health of broilers against $S$. pullorum infection as well as to improve the SOD activity of ileal mucosa and reduced MDA contents of jejunual and ileal mucosa (Wang, 2012).

It is also possible that antibacterial and antiviral effects of clinoptilolite might be in correlation with immunomodulatory properties. For instance, in long-term supplementation with clinoptilolite, a decreased prevalence of $E$. coli carrying certain antimicrobial resistance and virulence genes was documented (Jahanbakhsh et al., 2015). An influence of natural clinoptilolite on E. coli was also documented in another study on broilers in vivo (Wu Y. et al., 2013). In this study, a beneficial effect on intestinal parameters was measured, which was hypothesized to be based on a direct effect on the microbial population in the intestine. While the total count of E. coli was significantly reduced, a rise of Lactobacillus acidophilus occurred in parallel (Zarkovic et al., 2003). Similarly, clinoptilolite supplementation of Enterex ${ }^{\circledR}$, approved by the Cuban Drug Quality Control Agency, showed to be highly efficient in ameliorating diarrhea symptoms in several clinical studies on humans with acute diarrhea of different etiologies. Moreover, in cases where diarrhea symptoms were removed and the pathogenic agent was identified upon Enterex treatment antibiotics were additionally used to completely eliminate pathogenic bacteria from the intestinal lumen (Rodríguez-Fuentes et al., 1997). Therefore, this observed antidiarrheal activity may be in correlation with Enterex ${ }^{\circledR}$ effect on certain pathogenic bacteria count or the microbiota status in general rather than with a direct antibacterial effect, which would have to be confirmed by additional studies. Recently, a positive effect of a potentiated clinoptilolite material (Absorbatox ${ }^{\circledast}$ ) was also shown to reduce symptoms associated with endoscopically negative gastroesophageal reflux disease and non-steroidal anti-inflammatory drug-induced gastritis, where it significantly prevented mucosal erosion severity (Potgieter et al., 2014).

Similarly, antiviral properties for clinoptilolite in vitro were shown on the human adenovirus 5 , herpes simplex virus type 1, and the human enteroviruses coxsackievirus B5 and echovirus 7 (Grce and Pavelić, 2005). This effect may probably be attributed to a direct adhesion of the viral particles on clinoptilolite in vitro, which then inhibits viral entrance in 
the cells and viral replication. Even though no in vivo studies on clinoptilolite antiviral activity have been published thus far, positive immunomodulatory effects have been observed in patients treated for immunodeficiency disorders. In a study performed by Ivkovic et al. (2004), a significant increase in specific immunity cell counts, B lymphocite CD19+, T-helper cells $\mathrm{CD} 4+$, and activated T-lymphocytes HLA-DR+ were observed in subjects treated with tribomechanically micronized clinoptilolite. This effect was accompanied by significantly decreased natural immunity NK CD56+ cell counts. Again, standard blood count parameters of patients remained within normal referent values (Ivkovic et al., 2004).

A hypothesis for the observed clinoptilolite immunomodulatory effects may be the modulation of body defense mechanisms toward ROS. Indeed, ROS induces cell and tissue damage when the inflammation is initiated as a mechanism for restoration of the body's homeostasis. Any impairment of the host immune and inflammatory mechanisms in the longterm may cause other inflammatory disorders, e.g., chronic sinusitis, otitis media and osteomyelitis, or microbial overgrowth syndromes, such as bacterial vaginosis, or inflammatory bowel disorders. It is plausible, therefore, to assume that such disorders have the formation of biofilms in common due to the impaired immunological reaction of the host organism (Pincus, 2005). Indeed, previous studies have shown a link between the antioxidative effect and the stimulation of the immune system (Knight, 2000; Brambilla et al., 2008).

Clinoptilolite's positive immunomodulatory effects in similar conditions may be due to the interactions of clinoptilolite particles in the intestine with microfold cells (M-cells) (Figure 3). M-cells are found in the GALT of Peyer's patches, a rich lymphoid tissue that communicates with intestinal epithelial cells and the microbiome of the intestine by diverse immunomodulation processes as well as in the MALT of other parts of the gastrointestinal tract. These gastrointestinal cells are known to initiate mucosal immunity responses on the apical membrane of the M-cells and to allow the transport of microbes and particles across the epithelial cell layer from the gut lumen to the lamina propria where interactions with immune cells occur (Mabbott et al., 2013). While evaluating possible clinoptilolite immunomodulatory effects in the intestine, it should be emphasized that M-cells can uptake nano- and submicro-particles, which can probably induce changes in the redox homeostasis in a cell (Igarashi, 2015). These changes in the M-cells then affect the Peyers patches as well. It is important to note that M-cells apical and basolateral sides, which communicate with Peyers patches, are polarized (Society for Mucosal Immunology, 2012) and one may hypothesize that, due to this particular phenotype, $\mathrm{M}$-cells retain clinoptilolite particles or silica particles released from the clinoptilolite material (tuff), which do not enter the blood system (Nizet et al., 2018) and act locally on this tissue. Contrary to M-cells, other cells in the intestine cannot perform macropinocytosis and therefore cannot absorb negatively charged clinoptilolite particles or silica particles released from the clinoptilolite material (tuff) due to their rich negatively-charged glycoprotein-polysaccharide covering, glycocalix (Egberts et al., 1984). Some probiotics' metabolites, e.g., from the lactic acid bacteria, exert the same activating function on Peyers patches as we suggest for clinoptilolite particles or silica particles released from the clinoptilolite material (tuff) and improve intestinal wall integrity (Sung et al., 2016). Therefore, we propose that this clinoptilolite-induced M-cells' communication with Peyer's patches, as similarly shown by Pavelic et al. (2002), increases the immune response either through particle intake or microbiota effect as recently shown in dogs supplemented with the zeolite chabazite (Sabbioni et al., 2016), and in particular, stimulates IgA producing B lymphocytes (plasma cells), a defensive mechanism of the intestinal tract against pathogenic bacteria (Round and Mazmanian, 2009). In the paper by Nizet et al. (2018), however, (Egberts et al., 1984), no clinoptilolite particles were detected in the selected sections of the gut tissue. Even though the inspection of limited histopathological sections in this study cannot rule out the suggested hypothesis on clinoptilolite particles or silica particles released from clinoptilolite material (tuff) in activation of Peyer patches, experimental analysis of the observed local immunomodulatory effect should be conducted in more detail. Indeed, the microbiota-clinoptilolite interaction may also underlie the observed immunomodulatory mechanism as well. Indeed, a role of IgA was already described in the reduction of intestinal pro-inflammatory signaling and bacterial epitope expression as part of the innate immune mechanism that contributes to balancing antibodies' negative impact on the micriobiota status (Round and Mazmanian, 2009). Evidence was provided on the role of cross-talking between the adaptive immune system and gut microbiota by selective generation of immune responses to bacteria that consequently stimulate the innate system and production of IgA. By means of this mechanism, the host can detect new bacterial types and ignore previously encountered bacteria in the intestine (Peterson et al., 2007). This immunomodulatory effect of clinoptilolite was speculated to be the so-called 'silicate superantigen' response. The superantigens generally encompass some bacterial exotoxins and viral products with a potent non-specific immuno-stimulatory effect on large T-cells fractions. This immunostimulation occurs upon simultaneous interaction of the superantigen with MHC class II molecules and T-cell receptors. Superantigens bind to the variable $\mathrm{V} \beta$ region of the T-cell receptor or to CD28 and do not follow the peptide-binding pattern. An incredibly heterogeneous T-cell clonal activation occurs upon binding and different cytokines are produced massively (Proft and Fraser, 2016). The superantigen-activated T-lymphocytes provoke the cellular immune response and also the humoral immune response, as postulated by Emmer et al. (2014) in multiple sclerosis pathogenesis as well. Lymphocytes stimulation by silicates, which also act as superantigens, was already shown for different silicate materials in in vitro conditions and this mechanism may underlie immunomodulation activity of clinoptilolite in the intestine as well (Ueki et al., 1994; Aikoh et al., 1998). Even though the exact mechanisms remain elusive, one may speculate that clinoptilolite silica or released silica acts as a superantigen that promotes the formation of IgA producing plasma cells, which is dependent on the presence of superantigen-reactive $\mathrm{T}$ cells. A similar superantigen effect was already observed in 
Peyer's patches during milk-borne mouse mammary tumor virus infection (Cabrera et al., 2010). To our knowledge, no negative effects on immune cells or tissue were documented in the scientific literature so far. Also, we cannot rule out some other unrecognized immunomodulatory effects of clinoptilolite due to a direct interaction with human microbiome (Figure 3).

The majority of studies on clinoptilolite were done by using different, so-called activated materials to increase either the surface area or to improve the clinoptilolite general adsorption or the ion-exchange capacity. Activation may be performed either through chemical treatment, e.g., with an acid, by replacing stabilizing cations, or through mechanical modifications by means of different micronization methods, which may all increase the surface area and change the ion-exchange properties and adsorption capacity (Abdulkerim, 2012; Akimkhan, 2012; Canli et al., 2013b). In the paper by Kraljević Pavelić et al. (2017), it was specifically shown that different micronization methods change the clinoptilolite tuff properties by affecting the surface area, pore size, and silicon to aluminum ratio on the surface of the material. Moreover, hydrochloric acid $(\mathrm{HCl})$ that is also present in the stomach may change clinoptilolite physical chemical properties and has been proven to enhance the clinoptilolite ion-exchange capacity for $\mathrm{Cu}^{2+}$ and $\mathrm{Co}^{2+}$ in a synthetic $\mathrm{Cu}-\mathrm{Co}$ solution at concentrations relevant for the stomach in vivo (0.1 M) (MambaI et al., 2010). Still, the clinoptilolite ion-exchange effects in vivo are complex and cannot be linearly explained as they are not affected only by the environmental conditions ( $\mathrm{pH}$, temperature, etc.) but also by the material composition and cation affinity properties. In a recent article, Turkish clinoptilolite was activated with hydrogen peroxide, which acts as a weak acid, to improve $\mathrm{Ni}^{2+}$ ions removal from aqueous solutions (Çanli and Abali, 2016). The authors show changes on the clinoptilolite surface upon activation that resulted in an improved Ni-ions absorption. This is important, as hydrogen peroxide dissociates into hydrogen ion $\mathrm{H}^{+}$and hydrogen peroxide radical $\left(\mathrm{HO}_{2}^{\bullet}\right)^{-}$, and during the acid-activation process $\mathrm{H}^{+}$ions are brought to the negativelycharged species on the material surface. As a consequence, dealumination of the surface occurs, which increases the $\mathrm{Si} / \mathrm{Al}$ surface ratio and absorption capacity for metal cations. This is a well-known process in industrial applications, while for the in vivo applications it may also hold certain relevance. In vivo, the acid concentrations of the intestine are substantially lower than those used in industrial activation process. For instance, gastric acid in the stomach contains $\mathrm{HCl}$ at $0.05-0.1 \mathrm{M}$. In such an environment, a certain release of $\mathrm{Al}$ species from the clinoptilolite surface may well be hypothesized even though aluminum from the clinoptilolite materials does not enter the blood or accumulate in the body as shown in athletes supplemented with zeolite-clinoptilolite supplement (Lamprecht et al., 2015) or healthy rats supplemented with different clinoptilolite materials (Kraljević Pavelić et al., 2017) where aluminum released into systemic circulation was observed only in rats supplemented with synthetic zeolite A. The latter effect was attributed to the zeolite A lower stability in the acidic $\mathrm{pH}$ relevant for the human intestine in comparison to clinoptilolite materials. In this study, authors

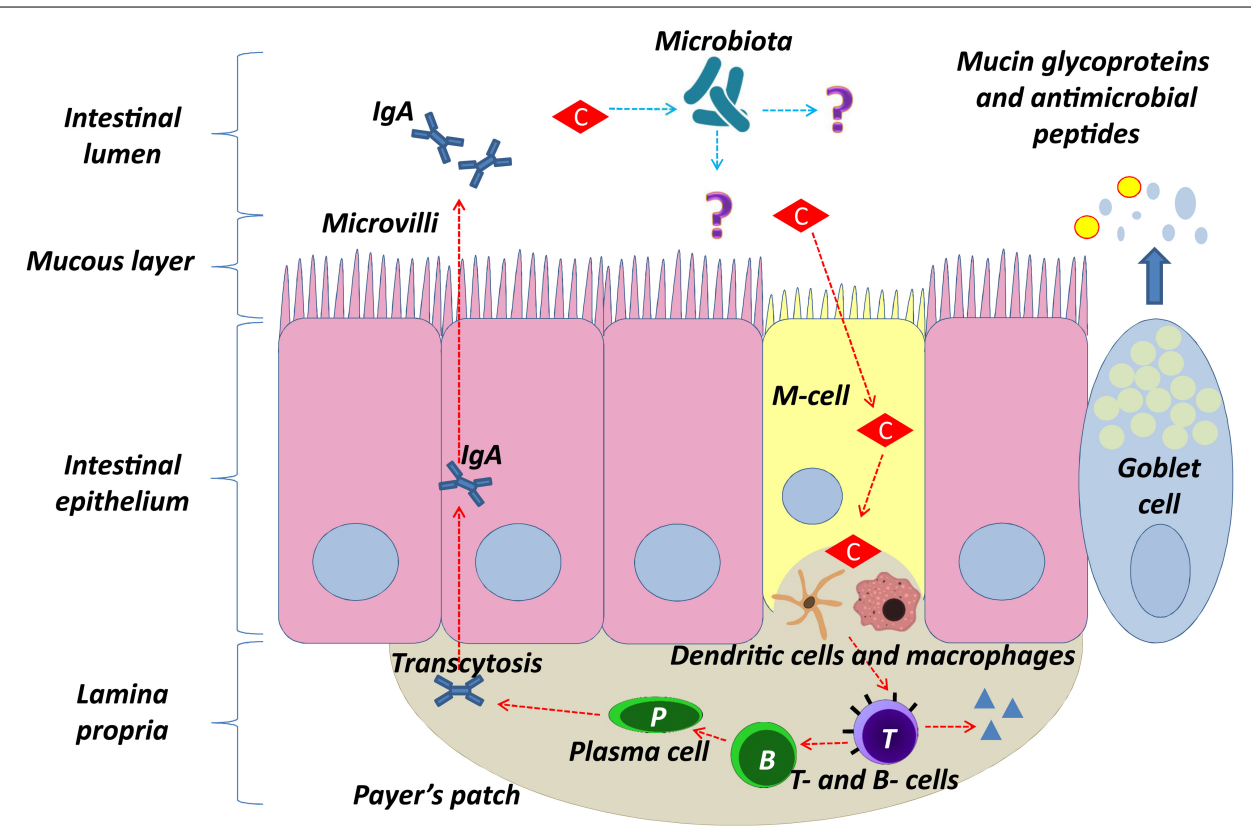

FIGURE 3 | Proposed model of clinoptilolite positive immunomodulatory effect in the intestinal epithelium (denoted with red arrows) through interaction of clinoptilolite tuff particles with microfold cells (M-cells). Clinoptilolite tuff released particles are denoted by 'C.' M-cells are hypothesized to transport luminal clinoptilolite tuff released particles across the epithelial barrier and present them to immunological cells (e.g., dendritic cells) in the lamina propria and the Peyer's patches. The latter are rich in T cells, macrophages, and clinoptilolite- activated lgA secreting B and plasma cells. The single layer of the intestinal epithelium is protected by mucus containing mucin glycoproteins where immunoglobulin A (lgA) and antimicrobial peptides prevent interaction of microbiota with the cell surface. Question marks (?) and blue arrows denote still unknown interactions of clinoptilolite with microbiota and microbiota with the lumen and epithelia. 
also proved that clinoptilolite materials were efficient in the removal of aluminum from aluminum chloride-intoxicated rats in vivo. These observations may be attributed to the clinoptilolite stability, the low bioavailability of $\mathrm{Al}$ species from water (around 0.1 to $0.4 \%$ ), and the immediate precipitation of $\mathrm{Al}$-species as non-soluble forms. Aluminum(III)-cation $\left(\mathrm{Al}^{3+}\right)$ has a generally strong affinity for anions which promote its precipitation. The $\mathrm{Al}^{3+}$ in most situations seeks out complexing agents with oxygen-atom donor sites, such as carboxylate or phosphate groups, e.g., from food in the intestine. However, it should be noted that the aqueous coordination chemistry of $\mathrm{Al}^{3+}$, especially in the living systems, is rather complex due to the Al-complexes' tendency to hydrolyze and form polynuclear species, which vary according to the $\mathrm{pH}$ condition of the medium (Wesley, 1996; Krewski et al., 2009). Interestingly, oral aluminum bioavailability is known to be increased by acidic $\mathrm{pH}$, such as the $\mathrm{pH}$ in the human intestine, but in case of clinoptilolite tuff, it may be decreased, as this is a silicon-containing compound that releases certain amounts of dissolved silica (Jurkić et al., 2013). Data has been provided on the ability of silicon-rich mineral water or silicic acid to remove Al from the human organism (Buffoli et al., 2013; Davenward et al., 2013), and this Si and Al relation has been recognized as the main evolutionary mechanism for fighting ecotoxicity of aluminum in living organisms. Water-soluble silica forms may thus be acknowledged as important contributors to fighting aluminum detrimental effects on human and animal health, especially nowadays when the exposure to bioavailable free aluminum cation poses a serious problem due to industrial development (Exley, 2009; Beardmore et al., 2016; Exley, 2016).

In addition, we hypothesize that previously observed data on antitumor properties of clinoptilolite in vitro may be due to the activation of clinoptilolite surface by acids. Even though in the majority of in vitro studies, the cells were grown in micronized clinoptilolite pre-treated growth media, no ultracentrifugation was employed, which means that a colloid system containing finest clinoptilolite particles was used for experiments (Pavelić et al., 2001b; Katic et al., 2006). For instance, it is well-known that tumor cells have increased hydrogen peroxide levels that regulate specific signaling pathways and hydrogen peroxide may modify cysteine residues on antioxidative enzymes (Lennicke et al., 2015). Enzymes are deactivated during modification. Clinoptilolite can react with hydrogen peroxide (Canli and Abali, 2016), similar to other silica particles, and, in such situations, oxidative stress is induced either through the breakdown of hydrogen peroxides to hydroxyl radicals or through the breakdown of hydrogen peroxides and production of the hydroperoxyl radicals (Rochette and Vergely, 2008). Therefore, it is possible that the contact between clinoptilolite and tumor cells with increased hydrogen peroxide concentrations induces formation of free radicals; therefore, increases in the oxidative burden occur in tumor cells, which consequently die. Tumor cells are susceptible to increased oxidative stress and in our previous experiments, this effect was not visible or was lower in normal tested fibroblasts in vitro (Katic et al., 2006). Also, it cannot be ruled out that some clinoptilolite particles enter into tumor cells in vitro, as tumor cells are inherently depolarized (Yang and Brackenbury, 2013) and can uptake particles by endocytosis (Sincai et al., 2007). Recently, a new hypothesis has been suggested on the use of lipophilic anions that target cancer cells due to their distinct electrical properties (Forrest, 2015). As clinoptilolite particles are negatively-charged polyanions, they might also target cancer cells and induce additional oxidative stress upon entrance into the cytoplasm through hydrogen peroxide activation, increased production of ROS and its consequent depletion within the cell. The depletion of hydrogen peroxide and the increased ROS production during hydrogen peroxide reaction with a clinoptilolite surface may change the redox status of the cell, e.g., through inhibition of the transcription factor Nrf2. Indeed, in previous in vitro experiments on tumor cells, clinoptilolite antitumor effects were attributed to the modulation of the EGF-R, protein kinase $B$ $(\mathrm{PKB}) / \mathrm{Akt}$, and nuclear factor $\mathrm{kB}(\mathrm{NfkB})$ signaling. They are interconnected with ROS and activity of Nrf2 (Pavelić et al., 2001b; Katic et al., 2006). This might be highly relevant for the survival of cancer cells as Nrf2 bears a proliferative role. In tumor cells, Nrf2 is usually activated by ROS-induced oncogenes, such as KRAS and c-MYC (DeNicola, 2011), and inhibition of its activity may contribute to the apoptosis of tumor cells and abrogated tumor growth (Ryoo et al., 2016).

\section{CLINOPTILOLITE TOXICOLOGY IN ANIMALS AND HUMANS}

The basic structure of clinoptilolite is considered to be biologically neutral and non-toxic (Auerbach et al., 2003). EFSA recently released an expert opinion on the safety of natural zeolite clinoptilolite in vivo (EFSA Panel on Additives and Products or Substances used in Animal Feed, 2013). EFSA evaluated and proved the zeolite-clinoptilolite non-toxicity for animal feed at doses of $10000 \mathrm{mg} / \mathrm{kg}$. Oral consumption of this type of zeolite, due to its extreme chemical stability, in EFSA's opinion, does not represent a potential risk for in vivo applications (EFSA Panel on Additives and Products or Substances used in Animal Feed, 2013).

The first comprehensive acute, subchronic, and chronic toxicology evaluation of a clinoptilolite material in vivo was performed by Pavelić et al. (2001b). In this preclinical toxicology study, tribomechanically micronized clinoptilolite was evaluated at the 'Ruer Bošković' Institute in Zagreb, Croatia, according to the standards and regulations required at the time by the OECD. In that study, the effects associated with increasing exposure times were analyzed in three categories: (1) acute toxic responses up to 1 month in mice and rats, (2) subchronic toxic responses up to 3 months in mice and rats, and (3) chronic toxic responses up to 1 year in rats and 6 months in mice. Clinoptilolite was administered to the animals as a powder supplementing their usual diet. Toxicity studies were approached by setting a "limit" test, which means that high doses of the substance were applied during 15 or more days. Two doses were selected from the "limit" test, $400 \mathrm{mg} / \mathrm{mice} /$ day (3.2 times higher than the dose specified by the regulatory agency) and $1000 \mathrm{mg} / \mathrm{mice} /$ day ( 8 times higher). Recalculated from human use, they were 10 and 25 times higher than envisaged potential human exposure dosages 
( $60 \mathrm{~g} / 75 \mathrm{~kg}$ human body weight and $150 \mathrm{~g} / 75 \mathrm{~kg}$ human body weight). The results showed that the "limit" test doses of the substance did not cause death for mice. Therefore, the "up and down" test on mice was performed with doses ranging from 60 to $400 \mathrm{mg} / \mathrm{mice} /$ day. Again, no toxicity was observed. Classical acute, subacute, and chronic tests on rats and mice were performed as well. Oral (in diet) administration to mice and rats showed no effects or changes that could be correlated to tribomechanically micronized clinoptilolite-supplementation. In addition, earlier in Pond and Yen (1983) published the first study on the clinoptilolite effects on the reproduction and progeny growth in rats with or without cadmium presence. They have shown protective effects of clinoptilolite on hematocrit and hemoglobin levels as well as on cadmium levels in the liver of pigs fed with cadmium in the presence of clinoptilolite in comparison to animals fed only with addition of cadmium to the diet.

Similarly, in another study performed by the European Union Cosmetic Ingredient Review Expert Panel, natural clinoptilolite showed no effects on female rat reproductive performance and it proved non-genotoxic in the Ames bacterial test system (Elmore, 2003). Moreover, in an independent study performed by Martin-Kleiner et al. (2001) effects of tribomechanically micronized clinoptilolite on the serum chemistry and hematopoiesis were evaluated in mice. The authors showed that the ingestion of clinoptilolite was well-tolerated and substantiated by unchanged body mass in clinoptilolitesupplemented mice. An increased level of potassium by $20 \%$ was detected in mice receiving the clinoptilolite-rich diet, while other changes in the serum chemistry were not observed. Erythrocyte, hemoglobin, and platelet levels in peripheral blood were not affected by clinoptilolite supplementation either.

Also, Muck-Seler and Pivac (2003) studied the effects of tribomechanically micronized and non-micronized clinoptilolite materials on the serotonergic 5-hydroxytryptamine receptors $5-\mathrm{HT}(1 \mathrm{~A})$ and $5-\mathrm{HT}(1 \mathrm{~B})$ in the brain of nontumorous (control) and mammary carcinoma-bearing female mice. A reduced binding of $3[\mathrm{H}] 8$-hydroxy-2-(di-npropylamino)tetralin (3H-8-OH-DPAT) to $5-\mathrm{HT}(1 \mathrm{~A})$ receptors in mammary carcinoma-bearing mice was normalized in animals supplemented by tribomechanically-micronized clinoptilolite. Also, the administration of clinoptilolite materials did not affect the binding of $3 \mathrm{H}-8$-OH-DPAT to the studied receptors during prolonged administration. The authors speculated that the observed effects in tumorbearing mice may be in correlation with the electrolytes balance, or immune system response to supplementation. A neuroprotective effect was also documented by Basha et al. (2013). Safety of the material was also proven by Ivkovic et al. (2004) where no adverse reactions to tribomechanically micronized clinoptilolite supplementation were observed in immunodeficient patients.

Some concerns were raised in public on the possible lead leakage from the natural clinoptilolite materials into the intestine. Still, extremely high affinity of clinoptilolite to lead has been documented previously, where sorption of lead and cadmium $(\mathrm{Cd})$ on natural clinoptilolite was shown to be irreversible or very slowly reversible (Hamidpour et al., 2010), and, in particular, it was shown to be high in an acidic environment (Perić et al., 2004). These results were obtained in very simple in vitro models that may not adequately mimic human digestion. Furthermore, a high capacity of zeolite lead adsorption occurs in the $\mathrm{pH}$ range 3-11 (Payne and AbdelFattah, 2004) and the leaching of lead from lead-preloaded clinoptilolite occurs mainly in $\mathrm{pH}$ under 1 , which is not relevant to conditions in the human body, as shown by Petrakakis et al. (2007). The authors conducted the study according to the standard procedures, Toxicity Characteristic Leaching Procedure/Environmental protection agency/Resource Conservation and Recovery Act (TCLP/EPA/RCRA) (1311), EPA Methods 1310, 1320 and DIN 38414-S4, and provided evidence of the $\mathrm{pH}$ being the main factor affecting $\mathrm{Pb}$ leaching from clinoptilolite. Interestingly, in the $\mathrm{pH} 3$ and higher $\mathrm{Pb}$, the leakage was less than $1 \%$, while at $\mathrm{pH} 1$ the leakage was observed up to $20 \%$ of the initial lead content. Furthermore, the authors show that the re-adsorption of $\mathrm{Pb}$ particles that leach from the solid material may occur as well; for lead this process occurred at $\mathrm{pH} 1.5$ and 2 . The $\mathrm{Pb}$ leaching percentage may, in the authors' opinion, be generally correlated with an increasing initial load but is not affected by the agitation rate or particle size. Also, previously published results from trials on animals and human subjects showed a strong clinoptilolite detoxifying effect and reduction of $\mathrm{Pb}$ content in vivo. For instance, tissue lead concentrations in lead-intoxicated rats with or without clinoptilolite supplementation clearly show that $\mathrm{Pb}$ concentrations were not increased in animals fed with clinoptilolite and that the intoxication burden in animals can be even alleviated by clinoptilolite supplementation (Beltcheva et al., 2012, 2015; Basha et al., 2013a). Similarly, in the study by Fokas et al. (2004), clinoptilolite was added to the diet of growing pigs at $20 \mathrm{~g} / \mathrm{kg}$ and no significant increase of $\mathrm{Pb}$ concentration in blood and edible tissues was measured. In this study, however, $\mathrm{Pb}$ levels were not discussed in the context of stored $\mathrm{Pb}$ levels in the bones and $\mathrm{Pb}$ levels in the bones were not assessed. This is why definite conclusions on eventual lead fate in the blood and organism of animals fed with clinoptilolite supplemented diet in this study cannot, be conclusive. Moreover, a clinical study comprising 22 human subjects evaluated the effects of clinoptilolite treatment on chronic diseases which could be traced back to heavy metal poisoning. During treatment with activated clinoptilolite from 7 to 30 days in total, both urine and blood serum were collected and tested for heavy metals and electrolytes. In this study, the daily intake of activated clinoptilolite suspension was effective in removal of toxic heavy metals from the body via urine (Flowers et al., 2009). Urine is, indeed, important in elimination of lead released from the bones or body compartments, i.e., in chelation therapy where upon quenching of lead from different sites of the body it is expelled through urine (Flora et al., 2012). The high lead leakage from the material into the body is theoretically possible but this would eventually happen from tuff materials with extremely high content of lead where the theoretical absorption would be subject to many different 
physiological parameters and health conditions. Another clinical study on human subjects showed detoxifying effectiveness of clinoptilolite. A total of 102 heavy-metal contaminated men were investigated and decreased concentrations of harmful metals $(\mathrm{Cd}, \mathrm{Pb}, \mathrm{Cu}, \mathrm{Cr}$, and $\mathrm{Ni}$ ) were measured in their hair after a 30-day supplementation with clinoptilolite. This decrease in harmful metal concentrations was a result of the clinoptilolite detoxification function and probable restoration of the body mineral metabolism homeostasis (Zhakov, 2003). Importantly, while great danger exists in removing the physiologically important electrolytes from the serum in a classical detoxification process, this has not been observed in clinoptilolite trials both in humans and animals, where no substantial changes in physiologically relevant trace elements or vitamins were observed even after long-term administration (Papaioannou et al., 2002; Katsoulos et al., 2005b; Flowers et al., 2009).

In conclusion, clinoptilolite materials tested in the scientific literature proved to be generally safe for in vivo applications even though each material seems to retain its own physicalchemical characteristics and exerts specific biological effects that cannot be readily transferable to other materials. Different particle sizes, surface areas, and cation compositions may induce different biological effects and exert different levels of effectiveness. Biological effects and toxicology data should therefore be carefully evaluated according to the type of clinoptilolite material or clinoptilolite-based preparations used in a particular study or application. In this paper, the cited literature on clinoptilolite effects in vitro and in vivo provides data for clinoptilolite materials (tuffs) from different sources/continents, of different purity, chemical composition, and that were prepared for oral application by use of different milling processing methods. Moreover, the research goals and experimental designs were different. This is why no absolute generalization on the mechanisms of action for clinoptilolite materials (tuffs) may be done at this point. Still, presented studies provide intriguing data on positive medical effects for this type of materials, especially effects on the immune system and detoxification, all substantiated by so far presented safe profile. In the future, it would be highly helpful to gather scientific data on the direct relationship between specific clinoptilolite material properties and sources with positive or negative effects and mechanisms of action in vivo. This will fill in the current gaps in research presented so far as similarly suggested by Colella (2011). Collela also emphasized the variability and heterogeneity of the clinoptilolite material used in different applications and studies and suggested to study in detail the applications and mechanisms of clinoptilolite materials in light of known and well-established properties or behaviors.

\section{CONCLUSION}

In agreement with the scientific evidence presented in the literature so far, it can be generally stated that clinoptilolitebased materials, including the so-called activated materials, may be regarded as safe for in vivo consumption. A variety of highly positive effects on animal and human health were documented thus far for clinoptilolite-based materials. Due to clinoptilolite's remarkable ion-exchange and adsorption properties and consequent detoxifying effects, it has proven useful in the elimination of a variety of contaminants from the body or in amelioration of the intestinal status. An indirect systemic detoxification effect attributed to clinoptilolite-based material supplementation in the diet of both animals and humans was documented in other organs as well, e.g., liver. However, the observed positive systemic mechanisms are still not completely understood. We hypothesize that they may be at least partially attributed to the restoration of the human homeostasis due to local detoxification properties within the intestine, the release of dissolved silica forms from the clinoptilolite tuff that enter from the intestine into the blood, as well as to clinoptilolite's immunomodulatory effects. The observed local immunomodulatory effects of clinoptilolite involve the induction of immune responses through Peyer's patches and/or possible positive effects on microbial intestinal populations through still unknown mechanisms. These local effects may have a systemic 'echo' on the whole immune status as well, as observed in some studies.

Finally, clinoptilolite's antioxidant effects and restoration of antioxidant defense mechanisms may also be linked to the positive general systemic impact. However, conclusive statements on the exact applications and benefits of clinoptilolitebased materials in humans should be carefully investigated and analyzed for each specific clinoptilolite material as the mechanisms of action may have correlations with the specific material's physical and chemical properties. Currently, different clinoptilolite-containing materials are used in medical applications worldwide. These materials contain different percentages of clinoptilolite and different compositions. Also, clinoptilolite-containing natural tuffs come with small quantities of other trace elements, and clinoptilolite is always pre-loaded with various cations. Some of the alkaline ions contained in the crystal lattice, mainly $\mathrm{Na}^{+}, \mathrm{Ca}^{2+}, \mathrm{Mg}^{2}$, and $\mathrm{K}^{+}$, may be readily released during the ion-exchange process. While these parameters may not be that relevant for agricultural or industrial applications, veterinary and human applications would require a higher level of control via a quality control system in the production, both of the raw material and the final products. For example, a proper mining process with adequate cleaning, sieving, de-hydrating, and pre-milling processes, along with elemental and microbiological examination of the clinoptilolite materials, might be considered among essential requirements for ensuring purity and quality (in relation to the high clinoptilolite content in the tuff) of the final materials for in vivo consumption.

\section{AUTHOR CONTRIBUTIONS}

SKP generated the main idea and wrote the manuscript, generated and shaped presented hypotheses, performed literature search and analysis, prepared the figures and tables, discussed and systematized all literature data. JSM prepared parts related to clinical aspects of clinoptilolite effects in vivo, was involved in the preparation of the table. DG performed the literature search, 
participated in writing of the manuscript related to oxidative stress and immune system, and participated in shaping of the hypothesis of zeolite molecular effects in vivo. AF performed literature search on physical-chemical properties of clinoptilolite and wrote parts of the manuscript related to clinoptilolite chemistry. NP performed a critical review of data and literature, edited the paper content and its final content. KP performed literature search related to clinical aspects and toxicology, discussed clinical aspects, and helped to draft the manuscript.

\section{FUNDING}

We greatly acknowledge the support of the University of Rijeka (Grant Nos. 13.11.1.1.11 and 13.11.1.2.01). NP was funded by the European Research Council (ERC) Starting Independent Researcher Grant 278212, the European Research Council (ERC) Consolidator Grant No. 770827, the Serbian Ministry

\section{REFERENCES}

Abdulkerim, Y. (2012). Influence of acid activation on the ion-exchange properties of manisa-gordes clinoptilolite. Physicochem. Probl. Miner. Process. 48, 591-598.

Aikoh, T., Tomokuni, A., Matsukii, T., Hyodoh, F., Ueki, H., Otsuki, T., et al. (1998). Activation-induced cell death in human peripheral blood lymphocytes after stimulation with silicate in vitro. Int. J. Oncol. 12, 1355-1359. doi: 10.3892/ ijo.12.6.1355

Akimkhan, A. M. (2012). "Structural and ion-exchange properties of natural zeolite," in Ion Exchange Technologies, ed. A. Kilislioglu (Rijeka: InTech).

Aminov, R. I., and Mackie, R. I. (2007). Evolution and ecology of antibiotic resistance genes. FEMS Microbiol. Lett. 271, 147-161. doi: 10.1111/j.1574-6968. 2007.00757.x

Auerbach, S. M., Kathleen, A., Carrado, K. A., and Dutta, P. K. (2003). Handbook of Zeolite Science and Technology. New York, NY: CRC Press. doi: 10.1201/ 9780203911167

Baerlocher, C. H., McCusker, L. B., and Olson, D. H. (2007). Atlas of Zeolite Framework Types, 6th Edn. Amsterdam: Elsevier.

Basha, M. P., Begum, S., and Mir, B. A. (2013). Neuroprotective actions of clinoptilolite and ethylenediaminetetraacetic acid against lead-introduced toxicity in mice Mus musculus. Toxicol. Int. 20, 201-207. doi: 10.4103/09716580.121666

Beardmore, J., Lopez, X., Mujika, J. I., and Exley, C. (2016). What is the mechanism of formation of hydroxyaluminosilicates? Sci. Rep. 6:30913. doi: 10.1038/ srep30913

Beltcheva, M., Metcheva, R., Popov, N., Teodorova, S. E., Heredia-Rojas, J. A., Rodríguez-de la Fuente, A. O., et al. (2012). Modified natural clinoptilolite detoxifies small mammal's organism loaded with lead. Biol. Trace Elem. Res. 147, 180-188. doi: 10.1007/s12011-011-9278-4

Beltcheva, M., Metcheva, R., Topashka-Ancheva, M., Popov, N., Teodorova, S., Heredia-Rojas, J. A., et al. (2015). Zeolites versus lead toxicity. J. Bioequiv. Availab. 7, 12-29. doi: 10.1007/s12011-011-9278-4

Bibi, I. (2012). Mineralogy and Acid Neutralisation Mechanisms in Inland Acid Sulfate Environments. Doctoral Thesis, University of Sydney, Campertown.

Blanchard, G., Maunaye, M., and Martin, G. (1984). Removal of heavy metals from waters by means of natural zeolite. Water Res. 18, 1501-1507. doi: 10.1016/ 0043-1354(84)90124-6

Bogdanov, B., Georgiev, D., Angelova, K., and Yaneva, K. (2009). "Natural zeolites: Clinoptilolite Review," in International Science conference Economics and Society Development on the Base of Knowledge, Stara Zagora.

Bonferoni, M. C., Gerri, G., de' Gennaro, M., Juliano, C., and Caramella, C. (2007). $\mathrm{Zn}^{2+}$-exchanged clinoptilolite-rich rock as active carrier for antibiotics in antiacne topical therapy: in-vitro characterization and preliminary formulation studies. Appl. Clay Sci. 36, 95-102. doi: 10.1016/j.clay.2006.04.014 of Education and Science Project III44006, the Slovenian Research Agency (ARRS) Project Grant No. J1-8155, and the awards to establish the Farr Institute of Health Informatics Research, London, from the Medical Research Council, Arthritis Research UK, British Heart Foundation, Cancer Research UK, Chief Scientist Office, Economic and Social Research Council, Engineering and Physical Sciences Research Council, National Institute for Health Research, National Institute for Social Care and Health Research, and Wellcome Trust (Grant No. $\mathrm{MR} / \mathrm{K} 006584 / 1)$.

\section{ACKNOWLEDGMENTS}

We acknowledge the project "Research Infrastructure for Campus-based Laboratories at University of Rijeka," co-financed by European Regional Development Fund (ERDF).

Brambilla, D., Mancuso, C., Scuderi, M. R., Bosco, P., Cantarella, G., Lempereur, L., et al. (2008). The role of antioxidant supplement in immune system, neoplastic, and neurodegenerative disorders: a point of view for an assessment of the risk/benefit profile. Nutr. J. 7, 29-38. doi: 10.1186/1475-2891-7-29

Buffoli, B., Foglio, E., Borsani, E., Exley, C., Rezzani, R., and Rodella, L. F. (2013). Silicic acid in drinking water prevents age-related alterations in the endothelium-dependent vascular relaxation modulating eNOS and AQP1 expression in experimental mice: an immunohistochemical study. Acta Histochem. 115, 418-424. doi: 10.1016/j.acthis.2012.10.002

Cabrera, G., Vercelli, C., Burzyn, D., and Piazzon, I. (2010). Increases in $\operatorname{IgA}^{+} \mathrm{B}$ cells in Peyer's patches during milk-borne mouse mammary tumor virus infection are influenced by Toll-like receptor 4 and are completely dependent on the superantigen response. J. Gen. Virol. 91, 2814-2820. doi: 10.1099/vir.0. 023358-0

Canli, M., and Abali, Y. (2016). A novel Turkish natural zeolite (clinoptilolite) treated with hydrogen peroxide for $\mathrm{Ni}^{2+}$ ions removal from aqueous solutions. Desalin. Water Treat. 57, 6925-6935. doi: 10.1080/19443994.2015.10 11707

Çanli, M., and Abali, Y. (2016). A novel Turkish natural zeolite (clinoptilolite) treated with hydrogen peroxide for $\mathrm{Ni}^{2+}$ ions removal from aqueous solutions. Desalin. Water Treat. 57, 6925-6935. doi: 10.1080/19443994.2015.10 11707

Canli, M., Abali, Y. S., and Bayca, U. (2013a). Removal of methelyne blue by natural and $\mathrm{Ca}$ and $\mathrm{K}$-exchanged zeolite treated with hydrogen peroxide. Physicochem. Probl. Miner. Process. 49, 481-496.

Canli, M., Yuksel, A., and Ugur, S. B. (2013b). Removal of methylene blue by natural and $\mathrm{Ca}$ and $\mathrm{K}$-exchanged zeolite treated with hydrogen peroxide. Physicochem. Probl. Miner. Process. 49, 481-496.

Cejka, J. (2005). Zeolites and Ordered Mesoporous Materials: Progress and Prospects: The 1st FEZA School on Zeolites, Prague, Czech Republic. Oxford: Gulf Professional Publishing.

Chen, X., Song, M., Zhang, B., and Zhang, Y. (2016). Reactive oxygen species regulate $\mathrm{T}$ cell immune response in the tumor microenvironment. Oxid. Med. Cell. Longev. 2016:1580967. doi: 10.1155/2016/1580967

Colella, C. (2011). A critical reconsideration of biomedical and veterinary applications of natural zeolites. Clay Miner. 46, 295-309. doi: 10.1180/claymin. 2011.046.2.295

Covarrubias, L. (2008). Function of reactive oxygen species during animal development: passive or active? Dev. Biol. 320, 1-11. doi: 10.1016/j.ydbio.2008. 04.041

Cutovic, M., Lazovic, M., Vukovic-Dejanovic, V., Nikolic, D., PetronicMarkovic, I., and Cirovic, D. (2017). Clinoptilolite for treatment of dyslipidemia: preliminary efficacy study. J. Altern. Complement. Med. 23, 738744. doi: $10.1089 / \mathrm{acm} .2016 .0414$ 
Davenward, S., Bentham, P., Wright, J., Crome, P., Job, D., Polwart, A., et al. (2013). Silicon-rich mineral water as a non-invasive test of the 'aluminum hypothesis' in Alzheimer's disease. Alzheimers Dis. 33, 423-430. doi: 10.3233/JAD-2012121231

Demir, A., Günay, A., and Debik, E. (2002). Ammonium removal from aqueous solution by ion-exchange using packed bed natural zeolite. Water SA 28, 329-335. doi: 10.4314/wsa.v28i3.4903

DeNicola, G. M. (2011). Oncogene-induced Nrf2 transcription promotes ROS detoxification and tumorigenesis. Nature 475, 106-109. doi: 10.1038/ nature10189

Diaz-Sanchez, S., D’Souza, D., Biswas, D., and Hanning, I. (2015). Botanical alternatives to antibiotics for use in organic poultry production. Poult. Sci. 94, 1419-1430. doi: 10.3382/ps/pev014

Dimowa, L. T., Petrov, S. L., and Shivachev, B. L. (2013). Natural and Zn exchanged clinoptilolite: in situ high temperature XRD study of structural behavior and cation positions. Bulg. Chem. Commun. 45, 466-473.

Ding, C., Fan, X., and Wu, G. (2017). Peroxiredoxin 1 - an antioxidant enzyme in cancer. J. Cell. Mol. Med. 21, 193-202. doi: 10.1111/jcmm.12955

EFSA Panel on Additives and Products or Substances used in Animal Feed (2013). Scientific Opinion on the safety and efficacy of clinoptilolite of sedimentary origin for all animal species. EFSA J. 11, 1-14.

Egberts, H. J., Koninkx, J. F., van Dijk, J. E., and Mouwen, J. M. (1984). Biological and pathobiological aspects of the glycocalyx of the small intestinal epithelium. Vet. Q. 6, 186-199. doi: 10.1080/01652176.1984.9693936

Elmore, A. R. (2003). Cosmetic ingredient review expert panel final Report on the safety assessment of aluminum silicate, calcium silicate, magnesium aluminum silicate, magnesium silicate, magnesium trisilicate, sodium magnesium silicate, zirconium silicate, attapulgite, bentonite, Fuller's Earth, hectorite, kaolin, lithium magnesium silicate, lithium magnesium sodium silicate, montmorillonite, pyrophyllite, and zeolite. Int. J. Toxicol. 22, 37-102. doi: 10. $1177 / 1091581803022 S 115$

Emmer, A., Staege, M. S., and Kornhuber, M. E. (2014). The retrovirus/superantigen hypothesis of multiple sclerosis. Cell. Mol. Neurobiol. 34, 1087-1096. doi: 10.1007/s10571-014-0100-7

Erdem, E., Karapinar, N., and Donat, R. (2004). The removal of heavy metal cations by natural zeolites. J. Colloid Interface Sci. 280, 309-314. doi: 10.1016/j.jcis.2004. 08.028

Exley, C. (2009). Darwin, natural selection and the biological essentiality of aluminium and silicon. Trends Biochem. Sci. 34, 589-593. doi: 10.1016/j.tibs. 2009.07.006

Exley, C. (2016). The toxicity of aluminium in humans. Morphologie 100, 51-55. doi: 10.1016/j.morpho.2015.12.003

Federico, A., Dallio, M., Gravina, A. G., Iannotta, C., Romano, M., Rossetti, G., et al. (2015). A pilot study on the ability of clinoptilolite to absorb ethanol in vivo in healthy drinkers: effect of gender. J. Physiol. Pharmacol. 66, 441-447.

Flora, G., Gupta, D., and Tiwari, A. (2012). Toxicity of lead: a review with recent updates. Interdiscip. Toxicol. 5, 47-58. doi: 10.2478/v10102-012-0009-2

Flowers, J. L., Lonky, S. A., and Deitsch, E. J. (2009). Clinical evidence supporting the use of an activated clinoptilolite suspension as an agent to increase urinary excretion of toxic heavy metals. Nutr. Diet Suppl. 1, 11-18. doi: 10.2147/NDS. S8043

Fokas, P., Zervas, G., Fegeros, K., and Zoiopoulos, P. (2004). Assessment of Pb retention coefficient and nutrient utilization in growing pigs fed diets with added clinoptilolite. Anim. Feed Sci. Technol. 117, 121-129. doi: 10.1016/j. anifeedsci.2004.06.005

Forrest, M. D. (2015). Cancer cells have distinct electrical properties that predict a susceptibility to lipophilic anions; a new cancer drug paradigm. bioRxiv[Preprint]. doi: 10.1101/035113

Gaikwad, R. W., and Warade, A. R. (2014). Removal of nitrate from groundwater by using natural zeolite of Nizarneshwar Hills of Western India. J. Water Resour. Hydraul. Eng. 3, 74-80.

Gandy, J. J., Laurens, I., and Snyman, J. R. (2015). Potentiated clinoptilolite reduces signs and symptoms associated with veisalgia. Clin. Exp. Gastroenterol. 8, 271-277. doi: 10.2147/CEG.S81929

Garces, J. M. (1999). “Observations on zeolite applications," in Proceedings of the 12th International Conference on Zeolites, eds M. M. J. Treacz, B. K. Marcus, M. E. Misher, and J. B. Higgens (Warrendale, PA: Materials Research Society), $551-566$.
Ghiara, M. R., Petti, C., Franco, E., Lonis, R., Luxoro, S., and Gnazzo, L. (1999). Occurrence of clinoptilolite and modernite in tertiary calc-alkaline pyroclastites from Sardinia (Italy). Clays Clay Miner. 47, 319-328. doi: 10.1346/CCMN.1999. 0470308

Grce, M., and Pavelić, K. (2005). Antiviral properties of clinoptilolite. Microp. Mesop. Mater. 79, 165-169. doi: 10.1016/j.micromeso.2004.10.039

Gulam, W., and Ahsan, H. (2006). Reactive oxygen species: role in the development of cancer and various chronic conditions. J. Carcinog. 5, 1-8. doi: 10.1186/14773163-5-1

Hamid Said, M. (2018). Physiology of the Gastrointestinal Tract, Gut microbiome, 6th Edn, Vol. 1. London: Academic press, 744-749.

Hamidpour, M., Kalbasi, M., Afyuni, M., Shariatmadari, H., Holm, P. E., and Hansen, H. C. (2010). Sorption hysteresis of $\mathrm{Cd}(\mathrm{II})$ and $\mathrm{Pb}$ (II) on natural zeolite and bentonite. J. Hazard. Mater. 181, 686-691. doi: 10.1016/j.jhazmat.2010. 05.067

Hayakawa, K., Mouri, Y., Maeda, T., Satake, I., and Sato, M. (2000). Surfactant modified zeolites as a drug-carrier and the release of chloroquin. Colloid. Polym. Sci. 278, 553-558. doi: 10.1007/s003960050554

Hayyan, M., Hashim, M. A., and AlNashef, I. M. (2016). Superoxide ion: generation and chemical Implications. Chem. Rev. 116, 3029-3085. doi: 10.1021/acs. chemrev.5b00407

Hecht, K. (ed.) (2005). A Brief Comment on the Effect of Natural Clinoptilolite Zeolite in the Human Body, Information Material for Doctors, Naturopaths, Therapists, Pharmacists, Chemists, and Scientists. Berlin: Schibri-Verlag.

Herron, N. (1989). Zeolite catalysts as enzyme mimics. in: biocatalysis and biomimetics. Chapter 11, toward silicon-based life? ACS Symp. Ser. 392, 141154.

Hughes, R., and Magee, E. A. (2000). Bingham S., colonic protein metabolism and colorectal cancer. Curr. Issues Intest. Microbiol. 1, 51-58.

Igarashi, E. (2015). Nanomedicines and Nanoproducts: Applications, Disposition and Toxicology in Human Body. Boca Raton, FL: CRC Press. doi: 10.1201/b18211

Inoue, M., Sato, E. F., Nishikawa, M., Park, A. M., Kira, Y., Imada, I., et al. (2003). Mitochondrial Generation of reactive oxygen species and its role in aerobic life. Curr. Med. Chem. 10, 2495-2505. doi: 10.2174/0929867033456477

Ivkovic, S., Deutsch, U., Silberbach, A., Walraph, E., and Mannel, M. (2004). Dietary supplementation with an activated zeolite clinoptilolite in immunodeficiency: effects on the immune system. Adv. Ther. 21, 135-147. doi: 10.1007/BF02850340

Jahanbakhsh, S., Kabore, K. P., Fravalo, P., Letellier, A., and Fairbrother, J. M. (2015). Impact of medicated feed along with clay mineral supplementation on Escherichia coli resistance to antimicrobial agents in pigs after weaning in field conditions. Res. Vet. Sci. 102, 72-79. doi: 10.1016/j.rvsc.2015.07.014

Joughehdoust, S., and Manafi, S. (2008). "Application of zeolite in biomedical engineering: a review," in Proceedings of the Iran International Zeolite Conference (IIZC'08), Tehran.

Jurkić, L. M., Cepanec, I., Pavelić, S. K., and Pavelić, K. (2013). Biological and therapeutic effects of ortho-silicic acid and some ortho-silicic acid-releasing compounds: new perspectives for therapy. Nutr. Metab. 10, 1-12. doi: 10.1186/ 1743-7075-10-2

Katic, M., Bosnjak, B., Gall-Troselj, K., Dikic, I., and Pavelic, K. (2006) A clinoptilolite effect on cell media and the consequent effects on tumor cells in vitro. Front. Biosci. 11, 1722-1732. doi: 10.2741/1918

Katsoulos, P. D., Karatzia, M. A., Boscos, C., Wolf, P., and Karatzias, H. (2016). In-field evaluation of clinoptilolite feeding efficacy on the reduction of milk aflatoxin M1 concentration in dairy cattle. J. Anim. Sci. Technol. 58, 1-7. doi: 10.1186/s40781-016-0106-4

Katsoulos, P. D., Karatzia, M. A., Polizopoulou, Z., Florou-Paneri, P., and Karatzias, H. (2015). Effects of prolonged consumption of water with elevated nitrate levels on certain metabolic parameters of dairy cattle and use of clinoptilolite for their amelioration. Environ. Sci. Pollut. Res. Int. 22, 9119-9126. doi: 10.1007/s11356-014-4060-8

Katsoulos, P. D., Roubies, N., Panousis, N., Arsenos, G., Christaki, E., and Karatzias, H. (2005a). Effects of long-term dietary supplementation with clinoptilolite on incidence of parturient paresis and serum concentrations of total calcium, phosphate, magnesium, potassium, and sodium in dairy cows. Am. J. Vet. Res. 66, 2081-2085.

Katsoulos, P. D., Roubies, N., Panousis, N., and Karatzias, H. (2005b). Effects of long-term feeding dairy cows on a diet supplemented with clinoptilolite on certain serum trace elements. Biol. Trace Elem. Res. 108, 137-145. 
Katsoulos, P. D., Zarogiannis, S., Roubies, N., and Christodoulopoulos, G. (2009). Effect of long-term dietary supplementation with clinoptilolite on performance and selected serum biochemical values in dairy goats. Am. J. Vet. Res. 70, 346-352. doi: 10.2460/ajvr.70.3.346

Khalid, R. (2007). Studies on free radicals, antioxidants, and co-factors. Clin. Interv. Aging 2, 219-236.

Knight, J. A. (2000). Review: free radicals, antioxidants, and the immune system. Ann. Clin. Lab. Sci. 30, 145-158.

Kotova, D. L., Artamonova, M. N., Krysanova, T. A., Novikova, L. A., and Belchinskaya, L. I. (2016). Adsorption of water by clinoptilolite and glauconite. Orbital Chromatogr. Process. 16, 390-395.

Kraljević Pavelić, S., Micek, V., Filošević, A., Gumbarević, D., Žurga, P., Bulog, A., et al. (2017). Novel, oxygenated clinoptilolite material efficiently removes aluminium from aluminium chloride-intoxicated rats in vivo. Micropor. Mesopor. Mat. 249, 146-156. doi: 10.1016/j.micromeso.2017.04.062

Krewski, D., Yokel, R. A., Nieboer, E., Borchelt, D., Cohen, J., Harry, J., et al. (2009). Human health risk assesement for aluminum, aluminium oxide, and aluminium hydroxyde. J. Toxicol. Environ. Health B Crit. Rev. 10, 1-269. doi: 10.1080/10937400701597766

Lamprecht, M., Bogner, S., Steinbauer, K., Schuetz, B., Geilberger, J. F., Leber, B., et al. (2015). Effects of zeolite supplementation on parameters of intestinal barrier integrity, inflammation, redoxbiology and performance in aerobically trained subjects. J. Int. Soc. Sports Nutr. 12, 40-51. doi: 10.1186/s12970-0150101-z

Laurino, C., and Palmieri, B. (2015). "Zeolite the magic stone"; main nutritional, environmental, experimental and clinical fields of application. Nutr. Hosp. 32, $573-581$.

Lennicke, C., Rahn, J., Lichtenfels, R. A., Wessjohann, L. A., and Seliger, B. (2015). Hydrogen peroxide - production, fate and role in redox signaling of tumor cells. Cell Commun. Signal. 13, 13-39. doi: 10.1186/s12964-015-0118-6

Mabbott, N. A., Donaldson, D. S., Ohno, H., Williams, I. R., and Mahajan, A. (2013). Microfold (M) cells: important immunosurveillance posts in the intestinal epithelium. Mucosal Immunol. 6, 666-677. doi: 10.1038/mi.2013.30

Madhusudhan, N., Basha, P. M., Begum, S., and Ahmed, F. (2009). Fluoride induced neuronal oxidative stress and its amelioration by antioxidants in developing rats. Res. Rep. Fluoride 42, 179-187.

Maisanaba, S., Pichardo, S., Puerto, M., Gutiérrez-Praena, D., Cameán, A. M., and Jos, A. (2015). Toxicological evaluation of clay minerals and derived nanocomposites: a review. Environ. Res. 138, 233-254. doi: 10.1016/j.envres. 2014.12.024

Mallek, Z., Fendri, I., Khannous, L., Ben Hassena, A., Traore, A. I., Ayadi, M.-A., et al. (2012). Effect of zeolite (clinoptilolite) as feed additive in Tunisian broilers on the total flora, meat texture and the production of omega 3 polyunsaturated fatty acid. Lipids Health Dis. 11, 35-42. doi: 10.1186/1476-511X-11-35

MambaI, B. B., NyembeI, D. W., and Mulaba-Bafubiandi, A. F. (2010). The effect of conditioning with $\mathrm{NaCl}, \mathrm{KCl}$ and $\mathrm{HCl}$ on the performance of natural clinoptilolite's removal efficiency of $\mathrm{Cu}^{2+}$ and $\mathrm{Co}^{2+}$ from $\mathrm{Co} / \mathrm{Cu}$ synthetic solutions. Water SA 36, 437-444. doi: 10.4314/wsa.v36i4.58419

Martin-Kleiner, I., Flegar-Meštrić, Z., Zadro, R., Breljak, D., Stanović Janda, S., Stojković, R., et al. (2001). The effect of the zeolite clinoptilolite on serum chemistry and hematopoiesis in mice. Food Chem. Toxicol. 39, 717-727. doi: 10.1016/S0278-6915(01)00004-7

Miranda-Díaz, A. G., Pazarín-Villaseñor, L., Yanowsky-Escatell, F. G., and Andrade-Sierra, J. (2016). Oxidative stress in diabetic nephropathy with early chronic kidney disease. J. Diabetes Res. 2016, 1-7. doi: 10.1155/2016/ 7047238

Miranda-Trevino, J. C., and Coles, C. A. (2003). Kaolinite properties, structure and influence of metal retention on pH. Appl. Clay. Sci. 23, 133-139. doi: 10.1016/S0169-1317(03)00095-4

Mojzis, J., Nistiar, F., Kovac, G., and Mojzisova, G. (1994). Preventive effects of zeolite in swerer-rat intoxication with Vx-Substance. Vet. Med. 39, 443-449.

Montinaro, M., Uberti, D., Maccarinelli, G., Bonini, S. A., Ferrari-Toninelli, G., and Memo, M. (2013). Dietary zeolite supplementation reduces oxidative damage and plaque generation in the brain of an Alzheimer's disease mouse model. Life Sci. 20, 903-910. doi: 10.1016/j.lfs.2013.03.008

Morillas-Ruiz, J. M., and Hernández-Sánchez, P. (2015). "Oxidative stress and antioxidant defenses induced by physical exercise, basic principles and clinical significance of oxidative stress," in Basic Principles and Clinical Significance of Oxidative Stress, ed. S. J. T. Gowder (Rijeka: InTech).

Muck-Seler, D., and Pivac, N. (2003). The effect of natural clinoptilolite on the serotonergic receptors in the brain of mice with mammary carcinoma. Life Sci. 73, 2059-2069. doi: 10.1016/S0024-3205(03)00567-8

Mumpton, F. A. (1999). La roca magica: uses of natural zeolites in agriculture and industry. Proc. Natl. Acad. Sci. U.S.A. 96, 3463-3470. doi: 10.1073/pnas.96.7. 3463

Nizet, S., Muñoz, E., Fiebich, B. L., Abuja, P. M., Kashofer, K., Katloukal, K., et al. (2018). Clinoptilolite in dextran sulphate sodium-Induced murine colitis: efficacy and safety of a microparticulate preparation. Inflamm. Bowel Dis. 24, 54-66. doi: 10.1093/ibd/izx042

Oliveira, E. P., Burini, R. C., and Jeukendrup, A. (2014). Gastrointestinal complaints during exercise: prevalence etiology, and nutritional recommendations. Sports Med. 44, 79-85. doi: 10.1007/s40279-014-0153-2

Ortatatli, M., and Oğuz, H. (2001). Ameliorative effects of dietary clinoptilolite on pathological changes in broiler chickens during aflatoxicosis. Res. Vet. Sci. 71, 59-66. doi: 10.1053/rvsc.2001.0487

Papaioannou, D. S., Kyriakis, S. C., Papasteriadis, A., Roumbies, N., Yannakopoulos, A., and Alexopoulos, C. (2002). Effect of in-feed inclusion of a natural zeolite (clinoptilolite) on certain vitamin, macro and trace element concentrations in the blood, liver and kidney tissues of sows. Res. Vet. Sci. 72, 61-68. doi: 10.1053/rvsc.2001.0524

Patel, M. (2016). Targeting oxidative stress in central nervous system disorders. Trends Pharmacol. Sci. 37, 768-778. doi: 10.1016/j.tips.2016.06.007

Pavelić, K., Čolić, M., and Subotić, B. (2001a). "Chapter 32-O-01 biomedical application of zeolites," in Proceedings of the 13th International Zeolite Conference, Vol. 135, (Amsterdam: Elsevier).

Pavelić, K., Hadzija, M., Bedrica, L., Pavelić, J., Dikić, I., Katić, M., et al. (2001b). Natural zeolite clinoptilolite: new adjuvant in anticancer therapy. J. Mol. Med. $78,708-720$.

Pavelić, K., and Hadžija, M. (2003). "Medical applications of zeolites," in Handbook of Zeolites Science and Technology, eds S. M. Auerbach, A. Kathleen, K. A. Carrado, and P. K. Dutta (New York, NY: CRC Press), 1143-1173.

Pavelic, K., Katic, M., Sverko, V., Marotti, T., Bosnjak, B., Balog, T., et al. (2002). Immunostimulatory effect of natural clinoptilolite as a possible mechanism of its antimetastatic ability. J Cancer Res. Clin. Oncol. 128, 37-44. doi: 10.1007/ s00432-001-0301-6

Payne, K. B., and Abdel-Fattah, T. M. (2004). Adsorption of divalent lead Ions by zeolites and activated carbon: effects of $\mathrm{pH}$, temperature, and ionic strength. J. Environ. Sci. Health. A Toxiol. Hazard Subst. Environ. Eng. 39, 2275-2291. doi: 10.1081 /ESE-200026265

Payra, P., and Dutta, P. K. (2003). “A Primer," in Handbook Of Zeolites Science and Technology, eds S. M. Auerbach, A. Kathleen, A. Carrado, and P. K. Dutta (New York, NY: CRC Press), 1-19.

Perić, J., Trgo, M., and Vukojević Medvidović, N. (2004). Removal of zinc, copper and lead by natural zeolite - a comparison of adsorption isotherms. Water Res. 38, 1893-1899. doi: 10.1016/j.watres.2003.12.035

Peterson, D. A., McNulty, N. P., Guruge, J. L., and Gordon, J. I. (2007). IgA Response to symbiotic bacteria as a mediator of gut homeostasis. Cell Host Microbe 2, 328-339. doi: 10.1016/j.chom.2007.09.013

Petrakakis, Y., Mylona, E., Georgantas, D., and Grigoropoluou, H. (2007). Leaching of lead from clinoptilolite at acidic conditions. Glob. Nest J. 9, 207-213.

Pincus, S. (2005). Potential role of infections in chronic inflammatory diseases. ASM News 71, 529-535.

Pingitore, A., Lima, G. P., Mastorci, F., Quinones, A., Iervasi, G., and Vassalle, C. (2015). Exercise and oxidative stress: potential effects of antioxidant dietary strategies in sports. Nutrition 3, 916-922. doi: 10.1016/j.nut.2015. 02.005

Pond, W. G., and Yen, J. T. (1983). Reproduction and progeny growth in rats fed clinoptilolite in the presence or absence of dietary cadmium. Bull. Environ. Contam. Toxicol. 31, 666-672. doi: 10.1007/BF01606043

Potgieter, W., Samuels, C. S., and Snyman, J. R. (2014). Potentiated clinoptilolite: artificially enhanced aluminosilicate reduces symptoms associated with endoscopically negative gastroesophageal reflux disease and nonsteroidal antiinflammatory drug induced gastritis. Clin. Exp. Gastroenterol. 7, 215-220. doi: 10.2147/CEG.S51222 
Poulsen, H. D., and Oksbjerg, N. (1995). Effects of dietary inclusion of a zeolite (Clinoptilolite) on performance and protein - metabolism of young growing pigs. Anim. Feed Sci. Technol. 53, 297-303. doi: 10.1016/0377-8401(94)00744- T

Prasai, T. P., Walsh, K. B., Bhattarai, S. P., Midmore, D. J., Van, T. T. H., Moore, R. J., et al. (2016). Biochar, bentonite and zeolite supplemented feeding of layer chickens alters intestinal microbiota and reduces campylobacter load. PLoS One 1:e0154061. doi: 10.1371/journal.pone.0154061

Proft, T., and Fraser, J. D. (2016). "Streptococcal superantigens: biological properties and potential role in disease," in Streptococcus pyogenes: Basic Biology to Clinical Manifestations [Internet], eds J. J. Ferretti, D. L. Stevens, and V. A. Fischetti (Oklahoma City, OK: Oklahoma City University of Oklahoma Health Sciences Center).

Rahman, K. (2007). Studies on free radicals, antioxidants, and co-factors. Clin. Interv. Aging 2, 219-236.

Rochette, L., and Vergely, C. (2008). Forgotten radicals in biology. Int. J. Biomed. Sci. 4, 255-259.

Rodríguez-Fuentes, G., Barrios, M. A., Iraizoz, A., Perdomo, I., and Cedré, B. (1997). Enterex: anti-diarrheic drug based on purified natural clinoptilolite. Zeolites 19, 441-448. doi: 10.1016/S0144-2449(97)00087-0

Round, J. L., and Mazmanian, S. K. (2009). The gut microbiome shapes intestinal immune responses during health and disease. Nat. Rev. Immunol. 9, 313-323. doi: 10.1007/s00405-016-4058-6

Ryoo, I. G., Lee, S. H., and Kwak, M. K. (2016). Redox modulating NRF2: a potential mediator of cancer stem cell resistance. Oxid. Med. Cell. Longev. 2016, 1-14. doi: $10.1155 / 2016 / 2428153$

Sabbioni, A., Ferrario, C., Milani, C., Mancabelli, L., Riccardi, E., Di Ianni, F., et al. (2016). Modulation of the bifidobacterial communities of the dog microbiota by zeolite. Front. Microbiol. 7:1491. doi: 10.3389/fmicb.2016.01491

Saribeyoglu, K. (2011). Effects of clinoptilolite treatment on oxidative stress after partial hepatectomy in rats. Asian J. Surg. 34, 153-157. doi: 10.1016/j.asjsur. 2011.11.007

Selvam, T., Schwieger, W., and Dathe, W. (2014). Natural Cuban zeolites for medical use and their histamine binding capacity. Clay Miner. 49, 501-512. doi: 10.1180/claymin.2014.049.4.01

Sincai, M., Argherie, D., Ganga, D., and Bica, D. (2007). Comparative Study of Endocytosis between Normal Cells and Those that had Become Tumor Cells. Timisoara: Lucrãri ştiintifice medicinã veterinarã, 610-612.

Smilin Bell Aseervatham, G., Sivasudha, T., Jeyadevi, R., and Arul Ananth, D. (2013). Environmental factors and unhealthy lifestyle influence oxidative stress in humans-an overview. Environ. Sci. Pollut. Res. 20, 4356-4369. doi: 10.1007/ s11356-013-1748-0

Society for Mucosal Immunology (2012). in Principles of Mucosal Immunology, eds P. D. Smith, T. T. MacDonald, and R. S. Blumberg (New York, NY: Garland Science).

Soldatkin, O. O., Shelyakina, M. K., Arkhypova, V. N., Soy, E., Kirdeciler, S. K., Kasap, B. O., et al. (2015). Nano- and microsized zeolites as a perspective material for potentiometric biosensors creation. Nanoscale Res. Lett. 10, 59-69. doi: 10.1186/s11671-015-0768-8

Sprynskyy, M., Lebedynets, M., TerzykA, P., Kowalczyk, P., Namiesnik, J., and Buszewski, B. (2005). Ammonium sorption from aqueous solutions by the natural zeolite transcarpathian clinoptilolite studied under dynamic conditions. J. Colloid Interface Sci. 28, 408-415. doi: 10.1016/j.jcis.2004. 10.058

Srikanthan, K., Shapiro, J. I., and Sodhi, K. (2016). The role of Na/K-ATPase signaling in oxidative stress related to obesity and cardiovascular disease. Molecules 21, 1-13. doi: 10.3390/molecules 21091172

Sung, H. K., Jeung, W., Choi, I. D., Jeong, J. W., Lee, D. E., Huh, C. S., et al. (2016). Lactic acid bacteria improves Peyer's patch cell-mediated Immunoglobulin A and tight-junction expression in a destructed gut microbial environment. J. Microbiol. Biotechnol. 26, 1035-1045. doi: 10.4014/jmb.1512. 12002
Svoboda, D. L., and Šulcová, A. P. (2008). Characterization of kaolin dispersion using acoustic and electroacoustic spectroscopy. J. Min. Metall. B 44, 63-72. doi: 10.2298/JMMB0801063D

Tomasevic-Canovic, M., Dumic, M., Vukicevic, O., Duricic, M., and Jovanovic, S. (1996). Adsorption effects of mineral adsorbent on the clinoptilolite basis, part 2: adsorption behaviour in the presence of aminoacids and vitamins. Acta Vet. $46,227-234$.

Ueki, A., Yamaguchi, M., Ueki, H., Watanabe, Y., Ohsawa, G., Kinugawa, K., et al. (1994). Polyclonal human T-cell activation by silicate in vitro. Immunology 82 , 332-335.

Valko, M., Izakovic, M., Mazur, M., Rhodes, C. J., and Telser, J. (2004). Role of oxygen radicals in DNA damage and cancer incidence. Cell Biochem. 266, 37-56. doi: 10.1023/B:MCBI.0000049134.69131.89

Valpotić, H., Graèer, D., Turk, R., Đurièić, D., Vince, S., Folnožić, I., et al. (2017). Zeolite clinoptilolite nanoporous feed additive for animals of veterinary importance: potentials and limitations. Period Biol. 119, 159-172. doi: 10.18054/ pb.v119i3.5434

Wang, L. C. (2012). Protective effects of zinc-bearing clinoptilolite on broilers challenged with Salmonella pullorum. Poult. Sci. 91, 1838-1845. doi: 10.3382/ ps.2012-02284

Waterman, J. J., and Kapur, R. (2012). Upper gastrointestinal issues in athletes. Curr. Sports Med. Rep. 11, 99-104. doi: 10.1249/JSR.0b013e318249c311

Wesley, R. H. (1996). Speciation of aluminum in biological systems. J. Toxicol. Environ. Health 48, 543-568. doi: 10.1080/009841096161069

Wu, Q. J., Wang, L. C., Zhou, Y. M., Zhang, J. F., and Wang, T. (2013). Effects of clinoptilolite and modified clinoptilolite on the growth performance, intestinal microflora, and gut parameters of broiler. Poult. Sci. 92, 684-692. doi: 10.3382/ ps.2012-02308

Wu, Y., Wu, Q., Zhou, Y., Ahmad, H., and Wang, T. (2013). Effects of clinoptilolite on growth performance and antioxidant status in broilers. Biol. Trace Elem. Res. 155, 228-235. doi: 10.1007/s12011-013-9777-6

Yang, M., and Brackenbury, W. J. (2013). Membrane potential and cancer progression. Front. Physiol. 4:185. doi: 10.3389/fphys.2013. 00185

Yao, C. K., Muir, J. G., and Gibson, P. R. (2016). Insights into colonic protein fermentation, its modulation and potential health implications. Aliment. Pharmacol. Ther. 43, 181-196. doi: 10.1111/apt.13456

Zabochnichka-Światek, M., and Malinska, K. (2010). Removal of ammonia by clinoptilolite. Glob. Nest J. 12, 256-261.

Zamzow, M. J., Eichbaum, B. R., Sandgren, K. R., and Shanks, D. E. (1990). Removal of heavy metal and other cations from wastewater using zeolites, Sep. Sci. Technol. 25, 1555-1569. doi: 10.1080/01496399008050409

Zarkovic, N., Zarkovic, K., Kralj, M., Borovic, S., Sabolovic, S., Blazi, M. P., et al. (2003). Anticancer and antioxidative effects of micronized zeolite clinoptilolite. Anticancer Res. 23, 1589-1595.

Zhakov, Y. I. (2003). Clinical Testing of the Influence of Biologically Active Supplements (BAS) "Litovit" on the possibility of heavy metals excretion from the organism. Ministry of health of the Russian Federation. Chelyabinsk: Chelyabinsk State Medical Academy.

Conflict of Interest Statement: The authors declare that the research was conducted in the absence of any commercial or financial relationships that could be construed as a potential conflict of interest.

Copyright $\odot 2018$ Kraljević Pavelić, Simović Medica, Gumbarević, Filošević, Pržulj and Pavelić. This is an open-access article distributed under the terms of the Creative Commons Attribution License (CC BY). The use, distribution or reproduction in other forums is permitted, provided the original author(s) and the copyright owner(s) are credited and that the original publication in this journal is cited, in accordance with accepted academic practice. No use, distribution or reproduction is permitted which does not comply with these terms. 